\title{
Sphinganine-1-phosphate protects kidney and liver after hepatic ischemia and reperfusion in mice through $\mathrm{S}_{1} \mathrm{P}_{1}$ receptor activation
}

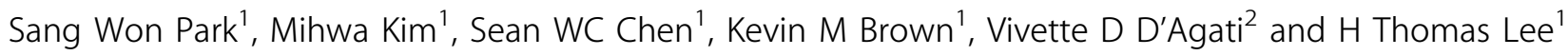

Liver failure due to ischemia and reperfusion (IR) and subsequent acute kidney injury are significant clinical problems. We showed previously that liver IR selectively reduced plasma sphinganine-1-phosphate levels without affecting sphingosine-1-phosphate (S1P) levels. Furthermore, exogenous sphinganine-1-phosphate protected against both liver and kidney injury induced by liver IR. In this study, we elucidated the signaling mechanisms of sphinganine-1-phosphate-mediated renal and hepatic protection. A selective $\mathrm{S}_{1} \mathrm{P}_{1}$ receptor antagonist blocked the hepatic and renal protective effects of sphinganine-1-phosphate, whereas a selective $\mathrm{S}_{1} \mathrm{P}_{2}$ or $\mathrm{S}_{1} \mathrm{P}_{3}$ receptor antagonist was without effect. Moreover, a selective $\mathrm{S}_{1} \mathrm{P}_{1}$ receptor agonist, SEW-2871, provided similar degree of liver and kidney protection compared with sphinganine-1phosphate. Furthermore, in vivo gene knockdown of $\mathrm{S}_{1} \mathrm{P}_{1}$ receptors with small interfering RNA abolished the hepatic and renal protective effects of sphinganine-1-phosphate. In contrast to sphinganine-1-phosphate, S1P's hepatic protection was enhanced with an $\mathrm{S}_{1} \mathrm{P}_{3}$ receptor antagonist. Inhibition of extracellular signal-regulated kinase, Akt or pertussis toxinsensitive G-proteins blocked sphinganine-1-phosphate-mediated liver and kidney protection in vivo. Taken together, our results show that sphinganine-1-phosphate provided renal and hepatic protection after liver IR injury in mice through selective activation of $\mathrm{S}_{1} \mathrm{P}_{1}$ receptors and pertussis toxin-sensitive G-proteins with subsequent activation of ERK and Akt. Laboratory Investigation (2010) 90, 1209-1224; doi:10.1038/labinvest.2010.102; published online 10 May 2010

KEYWORDS: Akt; dihydrosphingosine-1-phosphate; endothelial cell; extracellular signal-regulated kinase; necrosis; sphingolipid; sphingosine-1-phosphate

Hepatic ischemia and reperfusion (IR) is a major clinical problem complicating liver transplantation and major hepatic resection. ${ }^{1,2}$ Hepatic IR frequently leads to remote organ injury including the kidney, lung, and heart. ${ }^{3}$ In particular, acute kidney injury (AKI) after major liver IR is extremely common (40-85\% incidence) and the development of AKI after liver injury greatly increases patient mortality and morbidity during the perioperative period. ${ }^{3}$ We recently characterized a mouse model of AKI induced by liver IR with prominent early renal endothelial cell apoptosis and dysfunction with subsequent proximal tubule inflammation and necrosis. ${ }^{4}$ We also unexpectedly discovered rapid and profound depletion of a physiologically uncharacterized sphingolipid molecule sphinganine-1-phosphate (also called dihydrosphingosine-1-phosphate) in mouse plasma after hepatic IR. ${ }^{5}$ Moreover, we showed that exogenous repletion of sphinganine-1-phosphate provided a powerful protection against liver and kidney injury after liver IR in mice. ${ }^{5}$ We were able to show that mice treated with exogenous sphinganine-1-phosphate showed dramatically improved endothelial cell integrity and vascular dysfunction.

Unlike the better characterized cytoprotective effects of sphingosine-1-phosphate (S1P), the cellular mechanism(s) of sphinganine-1-phosphate-mediated liver and kidney protection after liver IR has not been elucidated. For example, in our earlier study, we implicated an S1P receptor using an

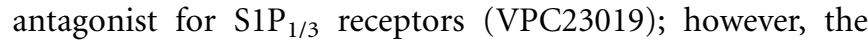
specific subtype of S1P receptor involved is still unclear. ${ }^{5}$ Activation of $\mathrm{S}_{1} \mathrm{P}_{1}$ receptors in vascular endothelial cells initiates several cytoprotective kinase signaling cascades including ERK mitogen-activated protein kinase (MAPK) and Akt through a pertussis toxin-sensitive G-protein

\footnotetext{
${ }^{1}$ Department of Anesthesiology, College of Physicians and Surgeons of Columbia University, New York, NY, USA and ${ }^{2}$ Department of Pathology, College of Physicians and Surgeons of Columbia University, New York, NY, USA

Correspondence: Associate Professor HT Lee, MD, PhD, Department of Anesthesiology, Anesthesiology Research Laboratories, Columbia University, P\&S Box 46 (PH-5), 630 West 168th Street, New York, NY 10032-3784, USA.
}

E-mail: t1128@columbia.edu

Received 4 November 2009; revised 11 March 2010; accepted 15 March 2010 
(Gi/o)-dependent pathway. ${ }^{6-8}$ As ERK MAPK and Akt signaling pathways are known to protect against endothelial cell apoptosis $^{9,10}$ and as hepatic IR-induced AKI directly causes renal endothelial cell apoptosis with subsequent vascular dysfunction and neutrophil infiltration, ${ }^{4}$ we hypothesized that sphinganine-1-phosphate through $\mathrm{S}_{1} \mathrm{P}_{1}$ receptor-mediated activation of ERK MAPK and Akt signaling pathways protect against renal endothelial cell apoptosis and reduce AKI after liver IR. In addition, we have shown previously that enhanced phosphorylation as well as increased synthesis of heat shock protein 27 (HSP27) protected against endothelial cell apoptosis and vascular compromise after hepatic IR. Therefore, we postulated that sphinganine-1-phosphate may also increase HSP27 phosphorylation and upregulation. Finally, as endothelial nitric oxide synthase (iNOS) upregulation with subsequently enhanced release of $\mathrm{NO}$ protects against vascular endothelial cell injury, and as S1P receptor activation is known to activate eNOS to increase NO levels in the vasculature, ${ }^{11}$ we postulated that sphinganine-1phosphate activation of $\mathrm{S}_{1} \mathrm{P}_{1}$ receptors may protect against liver and kidney injury through stimulating the eNOS pathway.

In this study, we tested the hypothesis that sphinganine-1phosphate protects against liver IR-induced hepatic and renal dysfunction through $\mathrm{S}_{1} \mathrm{P}_{1}$ receptor activation coupled to pertussis toxin-sensitive $\mathrm{G}$-proteins $(\mathrm{Gi} / \mathrm{o})$ with subsequent activation of cytoprotective kinases including ERK MAPK and Akt and induction of HSP27 and eNOS in the kidney and liver. We also determined in this study the S1P receptor subtype(s) involved in S1P-mediated hepatic and renal protection using both pharmacologic as well as gene knockdown approaches.

\section{MATERIALS AND METHODS Reagents}

Sphinganine-1-phosphate and (R)-3-amino-(3-hexylphenylamino)-4-oxobutylphosphonic acid (W146, a selective $\mathrm{S}_{1} \mathrm{P}_{1}$ receptor antagonist) were purchased from Avanti Polar Lipids (Alabaster, AL, USA). 5-[4-Phenyl-5-(trifluoromethyl)thiophen2-yl]-3-[3-(trifluoromethyl)phenyl] 1,2,4-oxadiazole (SEW-2871, a selective $\mathrm{S}_{1} \mathrm{P}_{1}$ receptor agonist) and 1-[1,3-dimethyl-4-(2methylethyl)-1H-pyrazolo[3,4-b] pyridin-6-yl]-4-(3,5-dichloro4-pyridinyl)-semicarbazide (JTE-013, a selective $\mathrm{S}_{1} \mathrm{P}_{2}$ receptor antagonist) were purchased from Tocris Bioscience (Ellisville, MO, USA). 2-Undecyl-thiazolidine-4-carboxylic acid (BML-241, a selective $\mathrm{S}_{\mathrm{P}} \mathrm{P}_{3}$ receptor antagonist) was purchased from Cayman Chemical (Ann Arbor, MI, USA). Wortmannin (a selective PI3K inhibitor) and L- $N^{5}$-(1-Iminoethyl)ornithine (L-NIO, a selective eNOS inhibitor) were purchased from EMD Chemicals (Gibbstown, NJ, USA). Unless otherwise specified, all other reagents including PD98059 (a selective MEK1 inhibitor) were purchased from Sigma (St Louis, MO, USA).

\section{Murine Model of Hepatic IR}

All protocols were approved by the Institutional Animal Care and Use Committee of Columbia University. Male C57BL/6 mice (20-25 g, Harlan, Indianapolis, IN, USA) were subjected to liver IR injury as described earlier. ${ }^{4}$ This method of partial hepatic ischemia for $60 \mathrm{~min}$ results in a segmental $(\sim 70 \%)$ hepatic ischemia but spares the right lobe of the liver and prevents mesenteric venous congestion by allowing portal decompression through the right and caudate lobes of the liver. Sham-operated mice were subjected to laparotomy and identical liver manipulations without the vascular occlusion. Plasma as well as liver and kidney tissues were collected $24 \mathrm{~h}$ after liver IR injury.

\section{Sphinganine-1-Phosphate Administration}

We have shown earlier that sphinganine-1-phosphate (0.01$0.1 \mathrm{mg} / \mathrm{kg}$ i.v. before reperfusion and $0.02-0.2 \mathrm{mg} / \mathrm{kg}$ s.c. $2 \mathrm{~h}$ after reperfusion) produced dose-dependent protection against liver and kidney injury after liver IR with the peak protection observed with the dose of $0.1 \mathrm{mg} / \mathrm{kg}$ i.v. before reperfusion and $0.2 \mathrm{mg} / \mathrm{kg}$ s.c. $2 \mathrm{~h}$ after reperfusion. ${ }^{5}$ In this study, sphinganine-1-phosphate was dissolved in warm $\left(50^{\circ} \mathrm{C}\right)$ methanol and the aliquots were stored at $-20^{\circ} \mathrm{C}$. The solution was evaporated under nitrogen immediately before use, and the powder was redissolved in $4 \mathrm{mg} / \mathrm{ml}$ fatty acidfree bovine serum albumin solution as a carrier as described by Van Brocklyn et al. ${ }^{12}$ The sphinganine-1-phosphate dose that produced the maximal liver and kidney protection was given to mice in this study $(0.1 \mathrm{mg} / \mathrm{kg}$ i.v. immediately before reperfusion and $0.2 \mathrm{mg} / \mathrm{kg}$ s.c. $2 \mathrm{~h}$ after reperfusion). Vehicletreated mice received injections of $0.4 \%$ fatty acid free BSA. We also tested whether a single injection of sphinganine-1phosphate also could provide liver and kidney protection after liver IR injury. In separate cohorts of mice, a single dose of sphinganine-1-phosphate was given immediately before $(0.1 \mathrm{mg} / \mathrm{kg}$ i.v. $)$ or $2 \mathrm{~h}$ after $(0.2 \mathrm{mg} / \mathrm{kg}$ s.c. $)$ reperfusion of the liver.

In another cohort of mice, we also gave a dose of S1P $(0.1 \mathrm{mg} / \mathrm{kg}$ i.v. immediately before reperfusion and $0.2 \mathrm{mg} / \mathrm{kg}$ s.c. $2 \mathrm{~h}$ after reperfusion dissolved in $4 \mathrm{mg} / \mathrm{ml}$ fatty acid-free bovine serum albumin solution) to test whether S1P also provided liver and kidney protection. Our preliminary data showed that sphinganine-1-phosphate, S1P or vehicle injection alone in sham-operated mice had no effect on any of the injury parameters tested in the liver or in the kidney.

\section{Plasma ALT Activity and Creatinine Level}

The plasma ALT activities were measured using the Infinity ALT assay kit according to the manufacturer's instructions (Thermo Fisher Scientific, Waltham, MA, USA). Plasma creatinine was measured by an enzymatic creatinine reagent kit according to the manufacturer's instructions (Thermo Fisher Scientific). This method of creatinine measurement largely eliminates the interferences from mouse plasma chromagens well known to the Jaffe method. ${ }^{13}$ 


\section{Determining S1P Receptor Subtype(s) Involved in Sphinganine-1-Phosphate- and S1P-Mediated Renal and Hepatic Protection after Liver IR}

To determine the S1P receptor subtype(s) involved in sphinganine-1-phosphate- and S1P-mediated renal and hepatic protection after liver IR, mice were treated with a selective $\mathrm{S}_{1} \mathrm{P}_{1}$ (W146, $0.05,0.1$, or $0.2 \mathrm{mg} / \mathrm{kg}$ i.p.), $\mathrm{S}_{1} \mathrm{P}_{2}$ (JTE-013: $0.05,0.1$ or $0.2 \mathrm{mg} / \mathrm{kg}$ i.p.), or $\mathrm{S}_{1} \mathrm{P}_{3}$ (BML-241, 0.05 or $0.1 \mathrm{mg} / \mathrm{kg}$ i.p.) receptor antagonist $20 \mathrm{~min}$ before sphinganine-1-phosphate or S1P treatment. In separate cohorts of mice, we also treated mice with the selective $\mathrm{S}_{1} \mathrm{P}_{1}$ receptor agonist SEW-2871 (1 mg/kg, i.p.) in lieu of sphinganine-1-phosphate $30 \mathrm{~min}$ before liver ischemia. The doses of $\mathrm{S}_{1} \mathrm{P}_{1}$ receptor antagonists and SEW-2871 were obtained from earlier in vivo studies. ${ }^{14-17}$

\section{siRNA Preparation and Delivery to Mice In Vivo}

A chemically synthesized 21 nucleotide stability-enhanced siRNA (siSTABLE) sequences specific for $\mathrm{S}_{1} \mathrm{P}_{1}$ receptors were custom made and purchased from Dharmacon Research (Lafayette, CO, USA) in 2'-hydroxyl, annealed, desalted, and dialyzed duplex form for in vivo use. The siSTABLE is a modified siRNA with improved resistance against nuclease degradation and enhanced silencing duration in vivo. The double-stranded sequence for S1P1 receptor siRNA was $5^{\prime}$-CC TGTGACATCCTGTACAA- $3^{\prime}$. Mice were injected with $50 \mu \mathrm{g}$ of siRNA $(100 \mu \mathrm{l})$ i.v. $48 \mathrm{~h}$ before liver ischemia.

\section{Potential Signaling Intermediates of Sphinganine-1- Phosphate-Mediated Renal and Hepatic Protection after Liver IR}

To test the hypothesis that ERK MAPK, Akt, and/or eNOS activation participate in sphinganine-1-phosphate-mediated protection against liver IR-induced AKI and liver injury, we pretreated the mice with PD98059 (an inhibitor of MEK1 to inhibit ERK phosphorylation, $1 \mathrm{mg} / \mathrm{kg}$, i.p.), wortmannin (an inhibitor of PI3K to inhibit Akt phosphorylation, $1 \mathrm{mg} / \mathrm{kg}$, i.p.) or L-NIO (an inhibitor of eNOS, $10 \mathrm{mg} / \mathrm{kg}$ i.p.) $20 \mathrm{~min}$ before sphinganine-1-phosphate treatment. The doses of PD98059 and wortmannin were selected based on earlier in vivo studies. ${ }^{6,18}$ In addition, we performed preliminary experiments to demonstrate that the dosage and method of administration of PD98059 and wortmannin we used effectively blocked the phosphorylation of ERK and Akt in vivo, respectively. ${ }^{6}$ The dose of L-NIO has been demonstrated previously to selectively block the eNOS activation in vivo. ${ }^{19}$ For determination of the role of pertussis toxin-sensitive G-protein (Gi/o) in sphinganine-1-phosphate-mediated renal and hepatic protection, mice were pretreated with pertussis toxin $(25 \mu \mathrm{g} / \mathrm{kg}$ i.p.) $48 \mathrm{~h}$ before sphinganine-1phosphate injection as described earlier. ${ }^{7,20}$

\section{Histological Evaluations of Hepatic and Renal Injury}

For histological preparations, liver or kidney tissues were fixed in $10 \%$ formalin solution overnight. After automated dehydration through a graded alcohol series, transverse liver or kidney slices were embedded in paraffin, sectioned at $4 \mu \mathrm{m}$, and stained with hematoxylin-eosin (H\&E). To quantify the degree of hepatic necrosis, H\&E stains were digitally photographed and the percent of necrotic area was quantified with NIH IMAGE (Image-J, 1.37v) software by a person (SWC) who was blinded to the treatment each animal had received. Twenty random sections were investigated per slide to determine the percentage of necrotic area. Liver $\mathrm{H} \& \mathrm{E}$ sections were also graded for IR injury by a pathologist (VDD) blinded to the samples using the system devised by Suzuki et al. ${ }^{21}$ In this classification, three liver injury indices are graded: sinusoidal congestion (0-4), hepatocyte necrosis $(0-4)$, and ballooning degeneration (0-4) are graded for a total score of $0-12$. No necrosis, congestion, or centrilobular ballooning is given a score of 0 , whereas severe congestion/ ballooning and $>60 \%$ lobular necrosis is given a value of 4 . Renal H\&E sections were evaluated for the severity (score: 0-3) of renal cortical vacuolization, peritubular/proximal tubule leukocyte infiltration, proximal tubule simplification, and proximal tubule hypereosinophilia by an experienced pathologist (VDD), who was blinded to the treatment each animal had received.

\section{Cell Culture}

Human renal glomerular endothelial cells (ScienCell Research Laboratories, Carlsbad, CA, USA) were grown in endothelial cell medium (consisting of $5 \%$ fetal bovine serum, $1 \%$ endothelial cell growth supplement plus 1\% of penicillin/ streptomycin solution, ScienCell Research Laboratories) at $37^{\circ} \mathrm{C}$ in a $100 \%$ humidified atmosphere of $5 \% \mathrm{CO}_{2}-95 \%$ air. These cells are not immortalized so they were plated and used when confluent. Human renal proximal tubule (HK-2, immortalized human proximal tubular cell line, American Type Culture Collection, Manassas, VA, USA) cells were grown and passaged in culture medium (50:50 mixture of DMEM low glucose and F12 plus $5 \%$ serum $)$ and antibiotics $(100 \mathrm{U} / \mathrm{ml}$ of penicillin $\mathrm{G}, 100 \mu \mathrm{g} / \mathrm{ml}$ of streptomycin, and $0.25 \mu \mathrm{g} / \mathrm{ml}$ of amphotericin B) at $37^{\circ} \mathrm{C}$ in a $100 \%$ humidified atmosphere of $5 \% \mathrm{CO}_{2}-95 \%$ air. Human renal endothelial cells or HK-2 cells were treated with $1 \mu \mathrm{M}$ sphinganine-1-phosphate for $5 \mathrm{~min}$ to $16 \mathrm{~h}$. We also pretreated some cells with $1 \mu \mathrm{M} \mathrm{W} 146$ (a selective $\mathrm{S}_{1} \mathrm{P}_{1}$ receptor antagonist) $30 \mathrm{~min}$ before sphinganine-1-phosphate treatment.

\section{Kidney and Liver Tissue Preparation and Immunoblotting Analyses}

For determination of the signaling pathways after sphinganine-1-phosphate injection, livers and kidneys were isolated $15 \mathrm{~min}$ after $0.1 \mathrm{mg} / \mathrm{kg}$ sphinganine-1-phosphate injection. Liver tissues or mouse kidney cortical tissues (including corticomedullary junction) were dissected on ice and immediately placed in ice-cold RIPA buffer $(150 \mathrm{mM} \mathrm{NaCl}$, $50 \mathrm{mM}$ Tris-HCl, $1 \mathrm{mM}$ EDTA, and $1 \%$ Triton-X (pH 7.4)) and homogenized for $10 \mathrm{~s}$ on ice. The samples were 
centrifuged for $30 \mathrm{~min}$ at $50000 \mathrm{~g}$. The supernatant was collected and used for immunoblotting as described earlier. ${ }^{6,18}$ We measured the phosphorylation of ERK MAPK, Akt, and HSP27, and the same blots were stripped and reprobed for total ERK MAPK, Akt, and HSP27.

\section{Immunoblot Analyses of Human Renal Endothelial Cells}

Immunoblotting analyses of human renal endothelial cell and proximal tubule (HK-2) cell lysates were performed as described earlier, ${ }^{8,22}$ after treating the cells with either sphinganine-1-phosphate or with vehicle $(0.4 \%$ BSA) for $5 \mathrm{~min}$ to $16 \mathrm{~h}$. The primary antibodies for phospho-ERK1/2 and total ERK were from Santa Cruz Biotechnologies (Santa Cruz, CA, USA). The primary antibody for phospho-Akt and total Akt1 were from Cell Signaling Technologies (Danvers, MA, USA). The primary antibodies for pHSP27 and HSP27 were obtained from Millipore (Billerica, MA, USA). All of the phospho-ERK, phospho-Akt, and phospho-HSP27 blots were stripped and reprobed for total ERK, Akt, and HSP27, respectively. The secondary antibody (goat anti-rabbit or anti-mouse IgG conjugated to horseradish peroxidase at 1:5000 dilution) was detected with enhanced chemiluminescence immunoblotting detection reagents (Amersham), with subsequent exposure to a CCD camera coupled to a UVP Bio-imaging System (Upland, CA, USA) and a personal computer. The band intensities of the immunoblots were within the linear range of exposure for all experiments.

\section{Reverse Transcription Polymerase Chain Reaction (RT-PCR) Analyses}

We also performed a semiquantitative RT-PCR assay for mouse HSP27 from total RNA extracted from renal cortices of mice injected either vehicle or with sphinganine-1-phosphate $5 \mathrm{~h}$ prior, as described earlier (Table 1 ). ${ }^{23}$ We also extracted total RNA from human renal endothelial cells or renal proximal tubule (HK-2) cells treated with either vehicle $(4 \mathrm{~h})$ or with sphinganine-1-phosphate $(2$ or $4 \mathrm{~h})$ and performed RT-PCR for human HSP27 as described (Table 1). ${ }^{23}$ To determine the specificity as well as the degree of reduction in $\mathrm{S}_{1} \mathrm{P}_{1}$ receptors after siRNA treatment in mice in vivo, we also performed semiquantitative RT-PCR assay for mouse $\mathrm{S} \mathrm{P}_{1-5}$ receptor subtypes in the kidney and liver tissues extracted $48 \mathrm{~h}$ after siRNA injection i.v. For each experiment, we also performed semiquantitative RT-PCR under conditions that yielded linear results for glyceraldehyde-3-phosphate dehydrogenase (Table 1) to confirm equal RNA input. RT-PCR products were analyzed on a $6 \%$ acrylamide gel stained with SYBR green (Invitrogen, Carlsbad, CA, USA) for analysis with a UVP Bio-imaging System (Upland, CA, USA). Semiquantitative analysis of mRNA expression gene was accomplished by obtaining the ratio of the band density of the mRNA's of interest to that of GAPDH (a housekeeping gene) from the same sample.

\section{Statistical Analysis}

All data are reported as mean \pm standard error. The overall significance of the results was examined using one-way

Table 1 RT-PCR primers used in this study

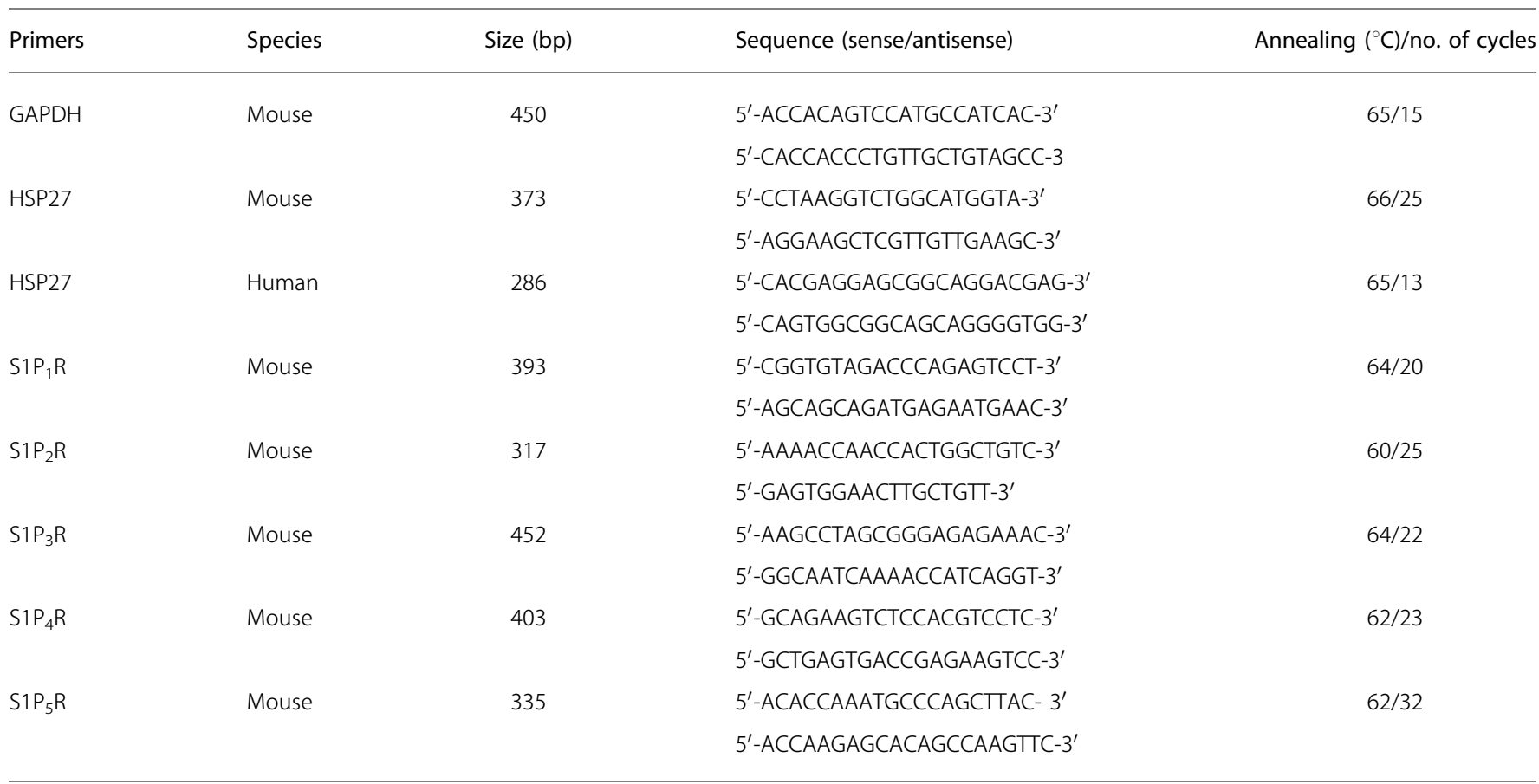


analysis of variance and the significant differences between the groups were considered at a $P<0.05$ with the appropriate Tukey's post hoc test made for multiple comparisons. The ordinal values of the liver and kidney injury scores were analyzed by the Mann-Whitney nonparametric test.

\section{RESULTS}

Sphinganine-1-Phosphate Protects against Hepatic and Renal Injury after Liver IR

The plasma level of ALT and creatinine ( $\mathrm{Cr}$ ) in the vehicletreated sham-operated mice was $72 \pm 9 \mathrm{U} / \mathrm{l}(N=6)$ and $0.43 \pm 0.03 \mathrm{mg} / \mathrm{dl}(N=6)$, respectively. The plasma level of ALT and $\mathrm{Cr}$ in the sphinganine-1-phosphate-treated shamoperated mice was $80 \pm 6 \mathrm{U} / \mathrm{l}(N=6)$ and $0.46 \pm 0.05 \mathrm{mg} / \mathrm{dl}$ $(N=6)$, respectively. The plasma level of ALT increased significantly $24 \mathrm{~h}$ after $60 \mathrm{~min}$ liver IR in mice treated with vehicle (15076 $\pm 1174 \mathrm{U} / \mathrm{l}, N=6$; Figure 1$)$. The mice subjected to liver IR after vehicle treatment also developed AKI with rises in plasma $\mathrm{Cr}(1.08 \pm 0.07 \mathrm{mg} / \mathrm{dl}, N=6, P<0.01 \mathrm{vs}$ sham-operated mice) $24 \mathrm{~h}$ after reperfusion. In contrast, for mice treated with sphinganine-1-phosphate $(0.1 \mathrm{mg} / \mathrm{kg}$ i.v. before reperfusion and $0.2 \mathrm{mg} / \mathrm{kg}$ s.c. $2 \mathrm{~h}$ after reperfusion), the increases in ALT $(7474 \pm 557 \mathrm{U} / 1, N=6, P<0.001$; Figure $1)$ and $\operatorname{Cr}(0.55 \pm 0.05 \mathrm{mg} / \mathrm{dl}, N=6, P<0.001$; Figure 1$)$ were significantly suppressed at $24 \mathrm{~h}$ after reperfusion. In this study, we also tested whether a single dose of sphinganine-1phosphate would provide hepatic and renal protection when given immediately before reperfusion $(0.1 \mathrm{mg} / \mathrm{kg}$ i.v. $)$ or $2 \mathrm{~h}$ after reperfusion $(0.2 \mathrm{mg} / \mathrm{kg}$ s.c.). We show that sphinganine1-phosphate given before reperfusion was protective $($ ALT $=7197 \pm 753 \mathrm{U} / \mathrm{l}, \quad N=6$ and $\mathrm{Cr}=0.58 \pm 0.06 \mathrm{mg} / \mathrm{dl}$, $N=6$ ), whereas the dose given $2 \mathrm{~h}$ after reperfusion was not protective (ALT $=14762 \pm 1732 \mathrm{U} / \mathrm{l}, N=6$ and $\mathrm{Cr}=0.98 \pm$ $0.06 \mathrm{mg} / \mathrm{dl}, \mathrm{N}=6)$.

We also tested whether exogenous S1P protected against liver IR-induced hepatic and renal dysfunction. S1P $(0.1 \mathrm{mg} / \mathrm{kg}$ i.v. before reperfusion and $0.2 \mathrm{mg} / \mathrm{kg}$ s.c. $2 \mathrm{~h}$ after reperfusion) also produced significant (but to a lesser degree than Sg1P) hepatic (ALT $=9178 \pm 1822 \mathrm{U} / \mathrm{l}, N=9)$ and renal protection $(\mathrm{Cr}=0.72 \pm 0.13 \mathrm{mg} / \mathrm{dl}, N=9) 24 \mathrm{~h}$ after liver IR.

\section{Sphinganine-1-Phosphate Provides Protection Against Hepatic and Renal Injury after Liver IR through S1P, Receptor Activation}

We also determined the S1P receptor subtype involved in sphinganine-1-phosphate-mediated hepatic and renal protection by pretreating mice with a highly selective pharmacological antagonist for $\mathrm{S}_{1} \mathrm{P}_{1}(\mathrm{~W} 146), \mathrm{S}_{2} \mathrm{P}_{2}$ (JTE-013), or $\mathrm{S}_{1} \mathrm{P}_{3}$ (BML-241) receptors. We found that blockade of $\mathrm{S}_{1} \mathrm{P}_{1}$ receptors but not $\mathrm{S}_{1} \mathrm{P}_{2}$ or $\mathrm{S}_{1} \mathrm{P}_{3}$ receptors blocked the sphinganine-1-phosphate-mediated liver and kidney protection after liver IR. W146 $(0.05-0.2 \mathrm{mg} / \mathrm{kg})$ caused complete inhibition of sphinganine-1-phosphate's protective effects against liver and kidney injury. For example, W146 at $0.05 \mathrm{mg} / \mathrm{kg}$ i.p. $10 \mathrm{~min}$ before liver ischemia completely

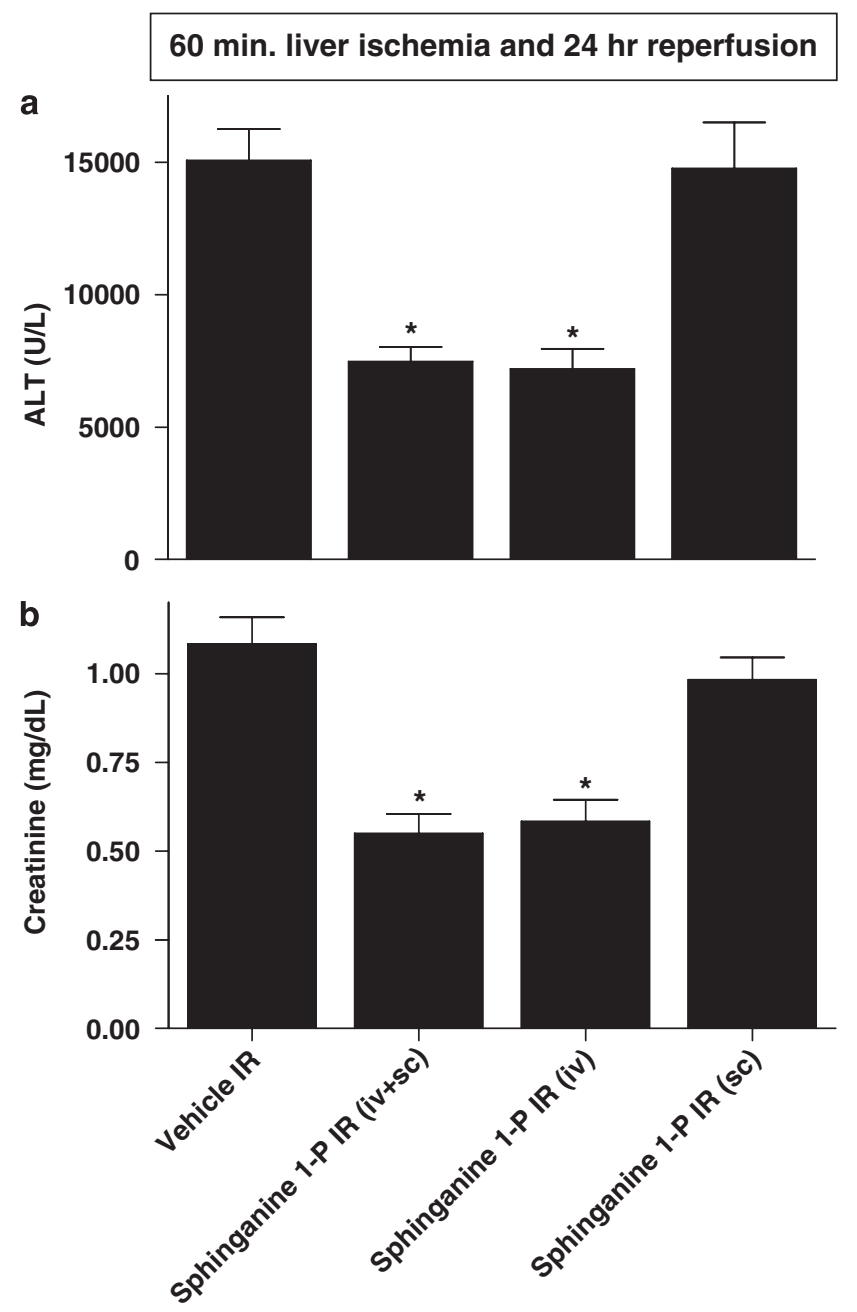

Figure 1 Sphinganine-1-phosphate administered $0.1 \mathrm{mg} / \mathrm{kg}$ i.v. immediately before reperfusion and $0.2 \mathrm{mg} / \mathrm{kg}$ s.c. $2 \mathrm{~h}$ after reperfusion (sphinganine-1-P IR (i.v. + s.c.), $N=6$ ) or $0.1 \mathrm{mg} / \mathrm{kg}$ i.v. immediately before reperfusion (sphinganine-1-P IR (i.v.), $N=6$ ) protects against hepatic (a, ALT) and renal (b, creatinine) injury in C57BL/6 mice subjected to $60 \mathrm{~min}$ liver ischemia and $24 \mathrm{~h}$ reperfusion. Sphinganine-1-phoshate when only given $2 \mathrm{~h}$ after reperfusion s.c. (sphinganine-1-P IR (s.c.), $N=6$ ) did not produce liver or kidney protection. Data are presented as mean \pm s.e.m. ${ }^{\star} P<0.05$ vs vehicle-treated IR (vehicle IR) group.

abolished the sphinganine-1-phosphate-induced hepatic and renal protection (Figure 2) $24 \mathrm{~h}$ after liver IR. SEW-2871, a selective $\mathrm{S}_{1} \mathrm{P}_{1}$ receptor agonist $(1 \mathrm{mg} / \mathrm{kg}$ i.p. $30 \mathrm{~min}$ before liver ischemia and $5 \mathrm{~min}$ before reperfusion) also provided equivalent degree of liver (ALT $=6502 \pm 552 \mathrm{U} / \mathrm{l}, N=6)$ and renal $(\mathrm{Cr}=0.63 \pm 0.08 \mathrm{mg} / \mathrm{dl}, N=6)$ protection when given in lieu of sphinganine-1-phosphate. Neither $\mathrm{S}_{1} \mathrm{P}_{2}$ nor $\mathrm{S}_{1} \mathrm{P}_{3}$ receptor antagonist prevented the sphinganine-1-phosphatemediated hepatic and renal protection against injury after liver IR (Figure 2).

Similar to sphinganine-1-phopshate, S1P-mediated hepatic and renal protection was inhibited by W146 (a selective S1P 1 receptor antagonist; Figure 2). Surprisingly, the S1P-mediated 

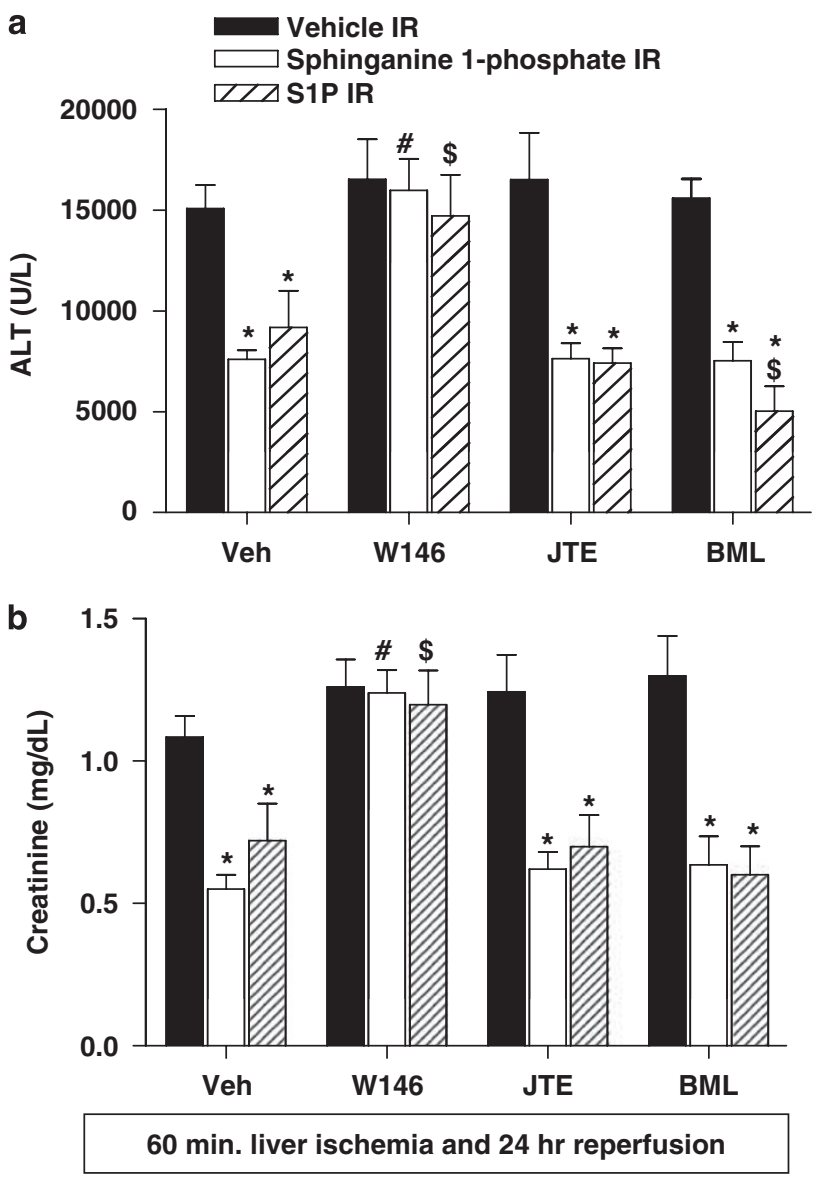

Figure 2 Selective $\mathrm{S}_{1} \mathrm{P}_{1}$ receptor antagonist W146 prevents hepatic (a, ALT) and renal (b, creatinine) protection by sphinganine-1-phosphate and S1P in C57BL/6 mice subjected to 60 min liver ischemia and $24 \mathrm{~h}$ reperfusion. Mice were pretreated with vehicle $(0.4 \%$ fatty acid free BSA, Veh, $N=6$ ), W146 (a selective $S 1 \mathrm{P}_{1}$ receptor antagonist, $0.05 \mathrm{mg} / \mathrm{kg}$ i.p., $N=6$ ), JTE-013 (JTE, a selective $\mathrm{S}_{1} \mathrm{P}_{2}$ receptor antagonist, $0.1 \mathrm{mg} / \mathrm{kg}$ i.p., $N=6$ ) or BML-241 (BML, a selective $\mathrm{S}_{1} \mathrm{P}_{3}$ receptor antagonist, $0.1 \mathrm{mg} / \mathrm{kg}$ i.p., $N=6) 20$ min before sphinganine-1-phosphate or S1P treatment. Sphinganine-1-phosphate or S1P was administered $0.1 \mathrm{mg} / \mathrm{kg}$ i.v. immediately before reperfusion and $0.2 \mathrm{mg} / \mathrm{kg}$ s.c. $2 \mathrm{~h}$ after reperfusion. Data are presented as means \pm s.e.m. ${ }^{\star} P<0.05$ vs vehicle-treated hepatic IR group. ${ }^{\#} P<0.05$ vs vehicle-treated sphinganine-1-phosphate hepatic IR group. ${ }^{\$} P<0.05$ vs vehicle-treated S1P hepatic IR group.

hepatic protection was significantly enhanced by an $\mathrm{S}_{3} \mathrm{P}_{3}$ receptor antagonist (BML-241; Figure 2). $\mathrm{S}_{2} \mathrm{P}_{2}$ receptor selective antagonist (JTE-013) has no effect on S1P-mediated hepatic and renal protection (Figure 2).

\section{In Vivo siRNA Targeting of S1P 1 Receptor Blocked Sphinganine-1-Phosphate-Induced Hepatic and Renal Protection after Liver IR}

Mice were injected with siSTABLE siRNA sequences specific for murine $\mathrm{S}_{1} \mathrm{P}_{1}$ receptors $48 \mathrm{~h}$ before liver ischemia. We first show that siRNA injection selectively and significantly reduced $\mathrm{S}_{1} \mathrm{P}_{1}$ receptor mRNA expression in the liver and kidney (Figure 3). We also show that selective knockdown of

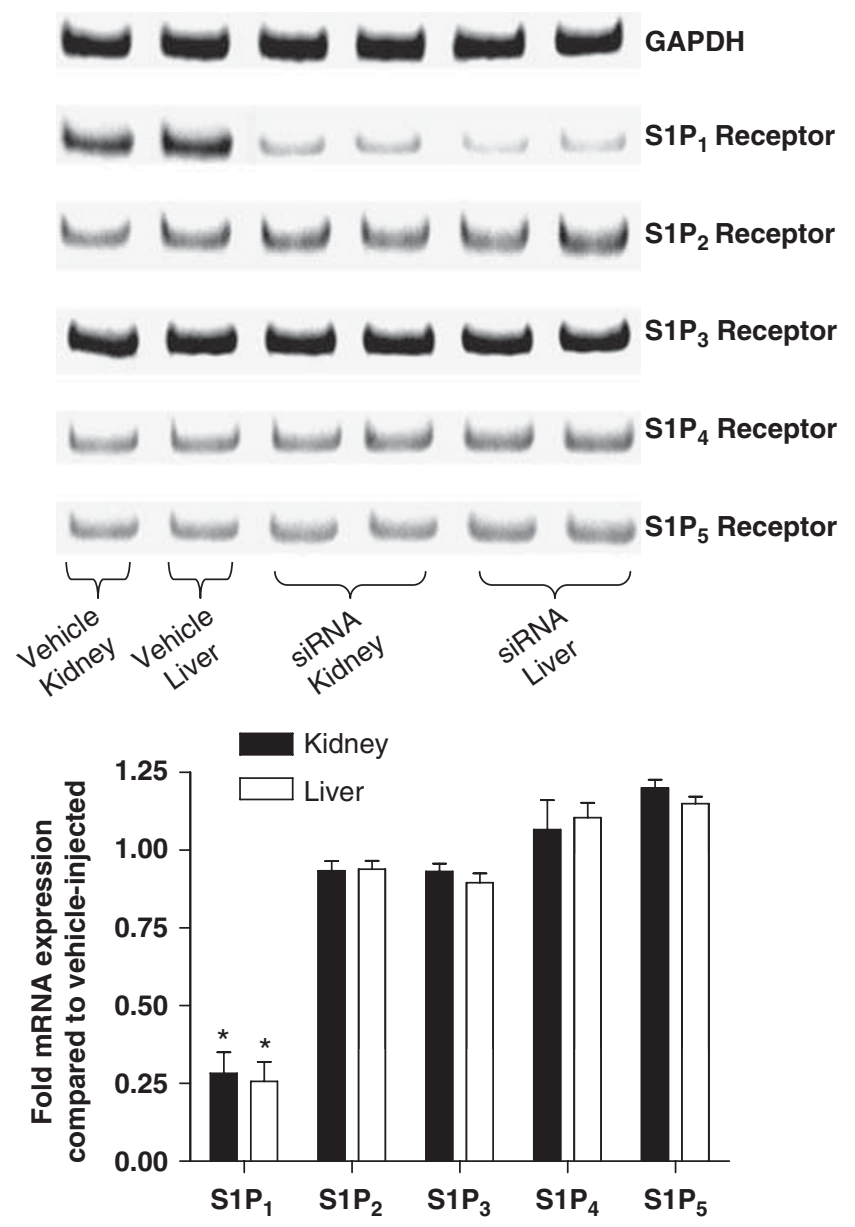

Figure 3 Mice injected with siSTABLE targeting $\mathrm{S}_{1} \mathrm{P}_{1}$ receptors show selective reduction in $\mathrm{S}_{1} \mathrm{P}_{1}$ receptor mRNA without affecting other S1P receptor subtypes $\left(\mathrm{S}_{1} \mathrm{P}_{2-5}\right)$. Densitometric quantification of relative $\mathrm{mRNA}$ band intensities normalized to GAPDH from RT-PCR reactions are shown in the bottom panel $(N=7)$. Data are presented as means \pm s.e.m. ${ }^{\star} P<0.05$ vs vehicle-injected mice.

$\mathrm{S}_{1} \mathrm{P}_{1}$ receptors with siRNA completely abolished the hepatic and renal protective effects of sphinganine-1-phosphate $(\mathrm{ALT}=15882 \pm 610 \mathrm{U} / \mathrm{l}, N=7$ and $\mathrm{Cr}=1.36 \pm 0.08 \mathrm{mg} / \mathrm{dl}$, $N=7, P<0.001$ vs sphinganine-1-phopshate injected mice subjected to liver IR). siSTABLE $\mathrm{S}_{1} \mathrm{P}_{1}$ siRNA injection had no effect on hepatic and renal function in vehicle injected mice subjected to liver IR (ALT $=16680 \pm 560 \mathrm{U} / \mathrm{l}, N=7$ and $\mathrm{Cr}=1.29 \pm 0.06 \mathrm{mg} / \mathrm{dl}, N=7)$.

\section{Signaling Pathways of Sphinganine-1-Phosphate- Mediated Renal Protection: Critical Role for the Pertussis Toxin-Sensitive G-Proteins (Gi/o), ERK, and Akt}

We probed the renal and hepatic protective signaling pathways activated by sphinganine-1-phosphate treatment in mice subjected to liver IR. To determine whether Gi/o, ERK MAPK, Akt, and/or eNOS signaling mediate the sphinganine-1-phosphate-mediated renal and hepatic protection after hepatic IR, mice were pretreated with pertussis toxin (an 
a
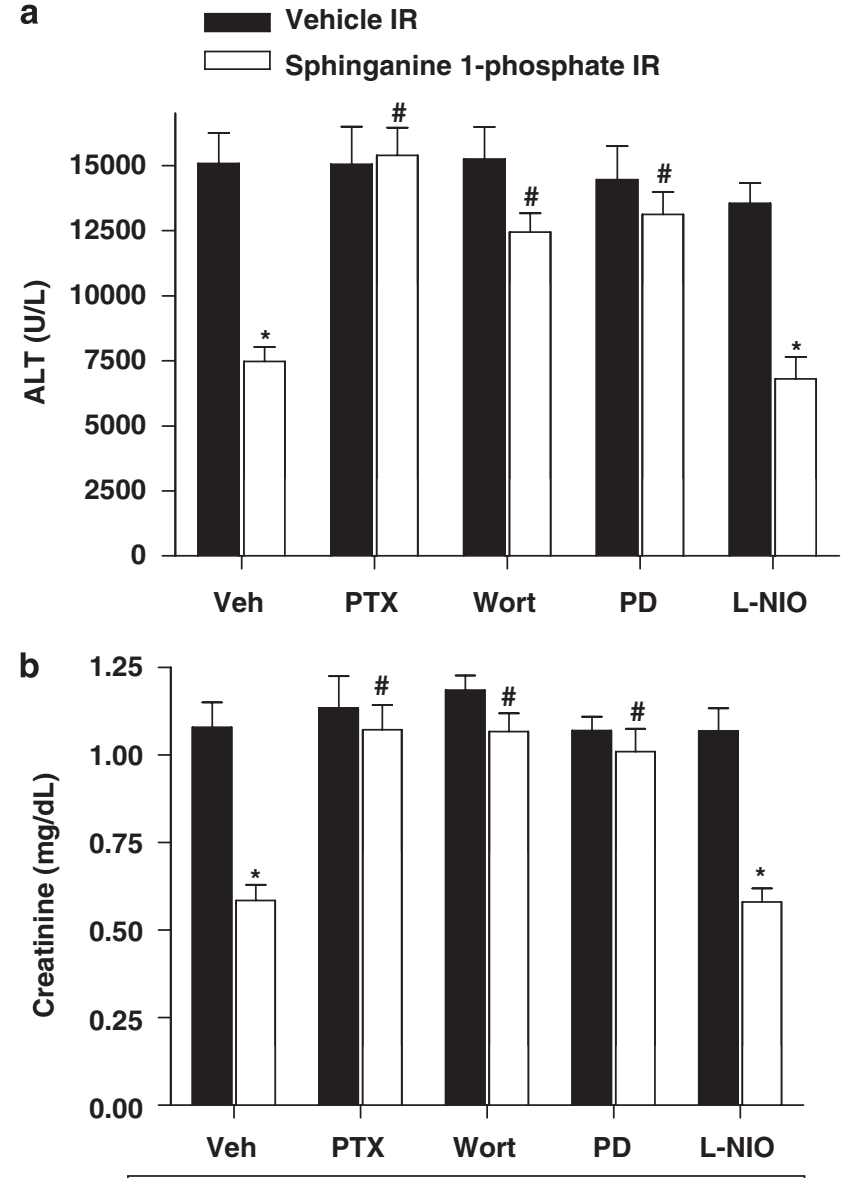

$60 \mathrm{~min}$. liver ischemia and $24 \mathrm{hr}$ reperfusion

Figure 4 Inhibition of pertussis toxin-sensitive G-proteins, ERK MAPK, or Akt but not eNOS prevents hepatic (a, ALT) and renal (b, creatinine) protection by sphinganine-1-phosphate in C57BL/6 mice subjected to $60 \mathrm{~min}$ liver ischemia and $24 \mathrm{~h}$ reperfusion. Mice were pretreated with PD98059 (PD, an inhibitor of MEK1 to inhibit ERK phosphorylation, $1 \mathrm{mg} / \mathrm{kg}$, i.p., $N=6$ ), with wortmannin (Wort, an inhibitor of PI3K to inhibit Akt phosphorylation, $1 \mathrm{mg} / \mathrm{kg}$, i.p., $N=6$ ) or with $N$-iminoethyl-L-ornithine (L-NIO, a selective inhibitor of eNOS, $10 \mathrm{mg} / \mathrm{kg}$ i.p. $N=6$ ) $20 \mathrm{~min}$ before vehicle or sphinganine-1-phosphate treatment. Some mice were pretreated with pertussis toxin (PTX, $25 \mu \mathrm{g} / \mathrm{kg}$, i.p.) $48 \mathrm{~h}$ before sphinganine-1phosphate treatment. Sphinganine-1-phosphate was administered $0.1 \mathrm{mg} / \mathrm{kg}$ i.v. immediately before reperfusion and $0.2 \mathrm{mg} / \mathrm{kg}$ s.c. $2 \mathrm{~h}$ after reperfusion. Data are presented as means \pm s.e.m. ${ }^{*} P<0.05$ vs vehicletreated IR group. ${ }^{\#} P<0.05$ vs vehicle-treated sphinganine-1-phosphatetreated hepatic IR group.

inhibitor of Gi/o signaling), PD98059 (a selective MEK1 inhibitor), wortmannin (a selective PI3K inhibitor) or L-NIO (a selective eNOS inhibitor) before sphinganine-1-phosphate treatment. We have shown earlier that the doses of pertussis toxin, PD98059, and wortmannin used effectively blocked phosphorylation of ERK and Akt, respectively, in mice in vivo. ${ }^{6,18}$ We found that the inhibition of Gi/o, MEK1, or PI3K prevented the renal and hepatic protection with sphinganine1-phosphate treatment after hepatic IR (Figure 4). A selective eNOS inhibitor (L-NIO) had no effects on sphinganine-1- phosphate-mediated hepatic and renal protection after liver IR (Figure 4). Inhibitors alone had no effect on renal function after IR injury (Figure 4).

\section{Sphinganine-1-Phosphate-Mediated Reduction in Hepatic Necrosis and Renal Injury are Blocked by a

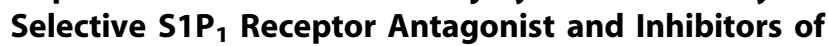 ERK MAPK, Akt, and Gi/o}

Representative histological slides (magnification, $\times 40$ ) from liver tissues from vehicle-treated or sphinganine-1-phosphate-treated mice subjected to $60 \mathrm{~min}$ ischemia and $24 \mathrm{~h}$ reperfusion or to sham operation are shown in Figure 5. Sixty minutes of partial hepatic IR in vehicle-treated mice produced large necrotic areas of livers after reperfusion (Figure 5). Correlating with significantly improved function, reduced necrosis was observed in mice treated with sphinganine-1phosphate and subjected to hepatic IR (Figure 5). The average percent necrotic areas for vehicle-treated mice were $92 \pm 2 \%(N=6)$ and sphinganine-1-phosphate treatment reduced this percent necrosis to $44 \pm 8 \%(N=7, P<0.05)$. We failed to detect necrosis in liver sections from shamoperated mice. Livers were also analyzed for the degree of hepatocellular damage using the Suzuki's criteria (Figure $5 \mathrm{~b}){ }^{24}$ The ischemic lobes in the control group showed severe hepatocyte vacuolization, necrosis, and sinusoidal congestion (Suzuki score $=8.7 \pm 0.3, N=5$ ). Mice treated with sphinganine-1-phosphate revealed significantly less necrosis/ sinusoidal congestion and better preservation of lobular architecture (Suzuki score $=5.2 \pm 0.8, N=5, P<0.01$; Figure $5 b)$. Pretreating mice with $\mathrm{W} 146$ (a selective $\mathrm{S}_{1} \mathrm{P}_{1}$ receptor antagonist), PD98059 (a selective MEK1 inhibitor), wortmannin (a selective PI3K inhibitor), or pertussis toxin (an inhibitor of Gi/o signaling) before sphinganine-1-phosphate treatment reduced the protective effects of sphinganine-1phosphate on liver histology. Necrotic areas in the liver after IR also increased significantly in mice treated with W146, PD98059, wortmannin, or pertussis toxin (data not shown).

Representative kidney H\&E slides from vehicle-treated and sphinganine-1-phosphate-treated mice subjected to $60 \mathrm{~min}$ ischemia and $24 \mathrm{~h}$ reperfusion are shown in Figure 6a (magnification, $\times 400$ ). When we examined the kidneys from the mice injected with vehicle and subjected to liver IR, we observed multifocal acute tubular injury including S3 segment proximal tubule necrosis, cortical tubular simplification, cytoplasmic vacuolization, and dilated lumina as well as focal granular bile/heme casts (Figure 6a). Correlating with significantly improved renal function, mice treated with sphinganine-1-phosphate showed less renal cortical vacuolization, peritubular/proximal tubule leukocyte infiltration, proximal tubule simplification, and proximal tubule hypereosinophilia (Figure 6a). The summary of renal injury scores for percent renal tubular hypereosinophilia, percent peritubular leukocyte margination, and percent cortical vacuolization are shown in Figure 6b. Blockade of $\mathrm{S}_{1} \mathrm{P}_{1}$ receptors, MEK1, PI3K, or Gi/o by pretreating mice with W146, 


\section{$a$
ह
क
는
원}
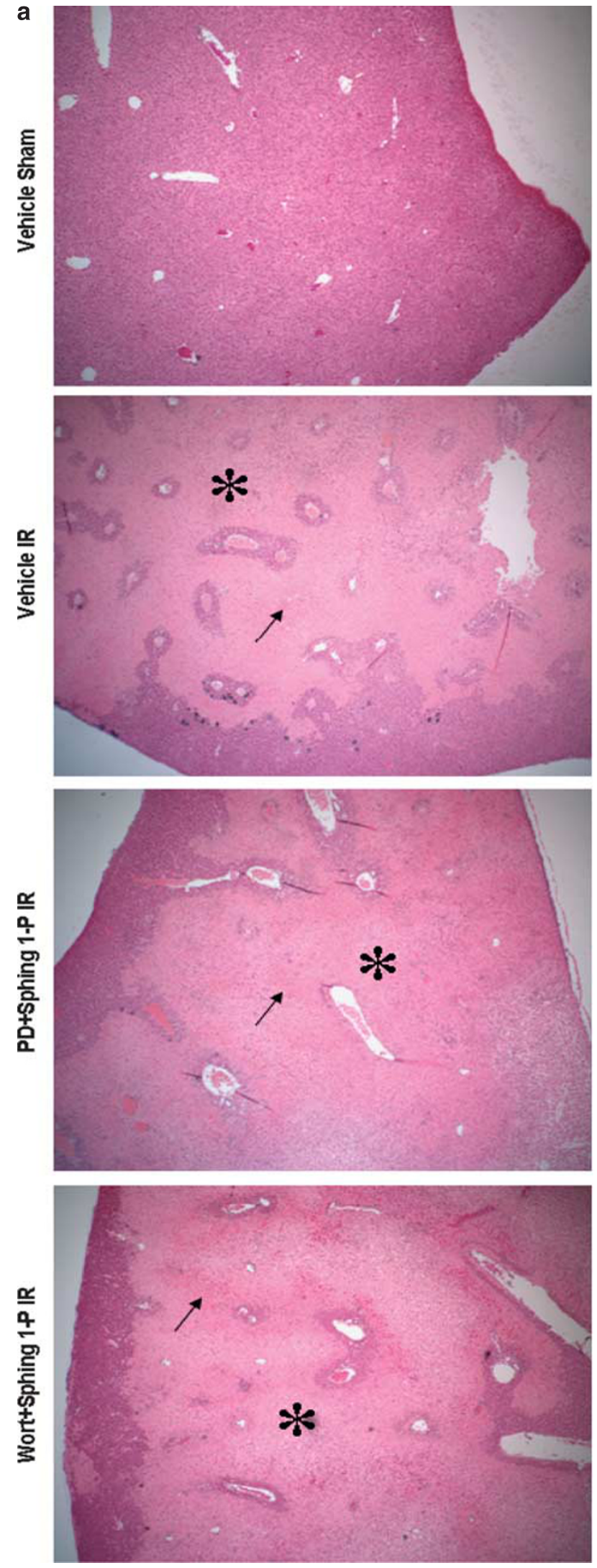

Figure 5 For caption see next page (continued).
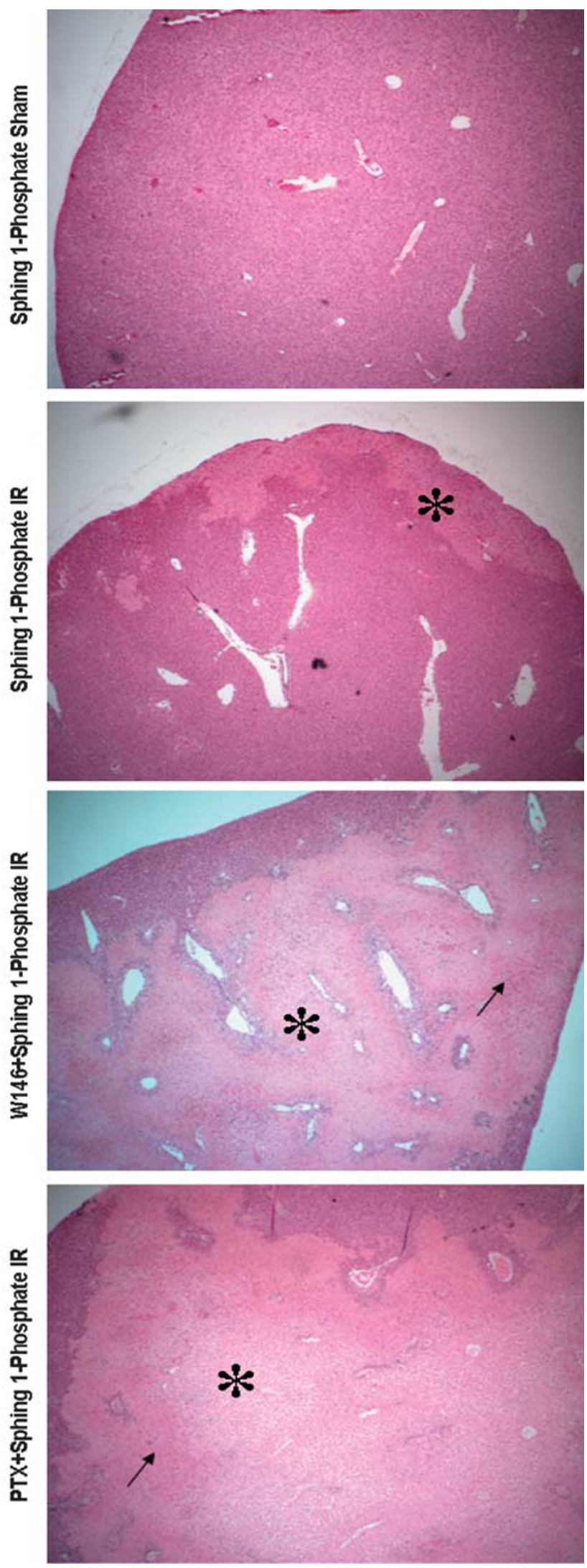


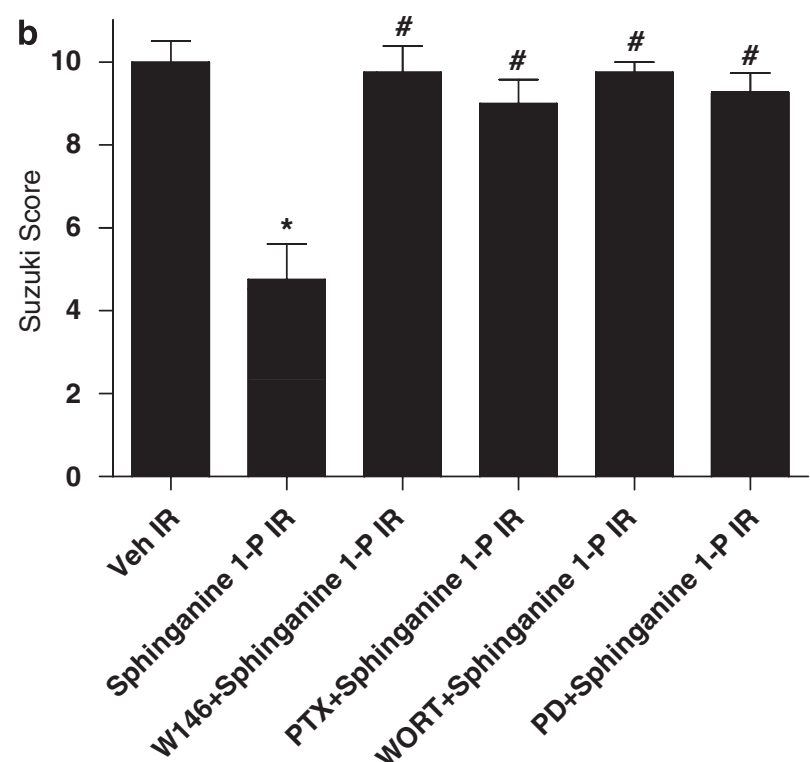

Figure 5 (a) Representative photomicrographs of hematoxylin and eosin staining of the liver sections $(\times 40)$. C57BL/6 mice were subjected liver ischemia reperfusion after vehicle- or sphinganine-1-phosphate treatment $(0.1 \mathrm{mg} / \mathrm{kg}$ i.v. immediately before reperfusion and $0.2 \mathrm{mg} / \mathrm{kg}$ s.c. $2 \mathrm{~h}$ after reperfusion). Necrotic hepatic tissue appears as light pink $\left(^{*}\right)$ with inflammation/vascular congestion near the portal triad (arrow). Some mice were pretreated with PD98059 (PD, an inhibitor of MEK1 to inhibit ERK phosphorylation, $1 \mathrm{mg} / \mathrm{kg}$, i.p., $N=6$ ) or with wortmannin (Wort, an inhibitor of PI3K to inhibit Akt phosphorylation, $1 \mathrm{mg} / \mathrm{kg}$, i.p., $N=6) 20 \mathrm{~min}$ before vehicle or sphinganine-1-phosphate treatment. Some mice were pretreated with pertussis toxin (PTX, $25 \mu \mathrm{g} / \mathrm{kg}$, i.p.) $48 \mathrm{~h}$ before sphinganine1-phosphate treatment. Photographs are representative of six independent experiments. (b). Summary of Suzuki liver injury scores (scale 0-12) from mice subjected to liver IR after vehicle or sphinganine-1-phosphate treatment. Mice pretreated with PD98059, wortmannin, or pertussis toxin showed increased indices of hepatic injury. ${ }^{*} P<0.05$ vs vehicle-treated IR group. ${ }^{\#} P<0.05$ vs sphinganine-1-phosphate-treated hepatic IR group.

PD98059, wortmannin, or pertussis toxin, respectively, before sphinganine-1-phosphate treatment reduced the protective effects of sphinganine-1-phosphate on renal histology (Figure 6b).

\section{Sphinganine-1-Phosphate Treatment Phosphorylates ERK MAPK, Akt, and HSP27 and Induces HSP27 mRNA and Protein in Mouse Kidney and Liver}

Mice were injected with sphinganine-1-phophate i.v. and their kidney and liver tissues were extracted at $15 \mathrm{~min}$ (for immunoblotting of phosphorylated proteins), at $5 \mathrm{~h}$ (for RTPCR) and at $24 \mathrm{~h}$ (for immunoblotting of total HSP27) after injection. Sphinganine-1-phosphate induced HSP27 mRNA of the liver and kidney in mice (Figure 7a). Sphinganine-1phosphate treatment also resulted in phosphorylation of ERK MAPK and Akt as well as phosphorylation of renal and hepatic HSP27 in mice (Figure 7b). Finally, we show that sphinganine-1-phosphate treatment increased total HSP27 protein in the liver and kidney in mice (Figure 7c).

\section{Sphinganine-1-Phosphate Phosphorylates ERK MAPK, Akt, and HSP27 and Induces HSP27 in Human Renal Endothelial Cells}

The next series of experiments were performed in cultured human renal vascular endothelial cells to further elucidate the mechanistic aspect of sphinganine-1-phosphate-mediated renal endothelial protection. Human renal endothelial cells were treated with sphinganine-1-phosphate and their mRNA and protein were extracted for analyses. Figure 8 a shows that sphinganine-1-phosphate induces HSP27 mRNA in cultured human renal endothelial cells. Figure $8 \mathrm{~b}$ shows that sphinganine-1-phosphate phosphorylates two well-known antiapoptotic kinases (ERK MAPK and AKT) in human renal endothelial cells in a time-dependent manner. Moreover, we also show that sphinganine-1-phosphate phosphorylates and induces HSP27 (Figure 8). Blockade of $\mathrm{S}_{1} \mathrm{P}_{1}$ receptors with W146 completely abolished the effects of sphinganine-1phosphate in human renal endothelial cells (data not shown). In contrast to the effects on human endothelial cells, sphinganine-1-phosphate failed to phosphorylate ERK MAPK, Akt, and HSP27 and induce HSP27 in HK-2 (human renal proximal tubule epithelial) cells (data not shown).

\section{DISCUSSION}

The major findings of this study are that sphinganine-1phosphate protects against liver IR-induced hepatic and renal injury through the activation of the $\mathrm{S}_{1} \mathrm{P}_{1}$ receptors with subsequent signaling through Gi/o, ERK, and Akt-mediated mechanisms (Figure 9). Both pharmacological (W146) as well as gene deletion approaches (with siSTANLE siRNA) showed essential roles for $\mathrm{S}_{1} \mathrm{P}_{1}$ receptors in sphinganine-1phosphate-mediated hepatic and renal protection after liver IR. Sphinganine-1-phosphate phosphorylated cytoprotective kinase ERK MAPK, Akt, and HSP27 in human glomerular renal endothelial cells in vitro as well as in mouse kidney and liver in vivo. However, sphinganine-1-phosphate failed to activate the cytoprotective kinase phosphorylation and HSP27 induction in human proximal tubule cells in culture. We also determined that sphinganine-1-phosphate-mediated liver and kidney protection is independent of the eNOS pathway in vivo. In contrast, the mechanisms of S1P-mediated hepatic protection are more complex as a selective $\mathrm{S}_{1} \mathrm{P}_{1}$ receptor antagonist blocked, whereas a selective $\mathrm{S}_{\mathrm{P}} \mathrm{P}_{3}$ receptor antagonist potentiated S1P's hepatic protective effects.

Development of AKI associated with liver injury is a devastating clinical complication with an extremely high mortality. ${ }^{3}$ Neither effective prevention nor therapy exists for hepatic IR-induced liver and kidney injury, and the current management remains largely supportive. ${ }^{2}$ We used a murine model of liver IR that not only produces severe liver dysfunction but also rapidly and reproducibly develops AKI with the degree of hepatic dysfunction directly correlating with the degree of AKI. ${ }^{4}$ Hepatic IR-induced AKI in mice mimicked the histological (renal tubular injury and juxtaglomerular apparatus hyperplasia) as well as biochemical 
a
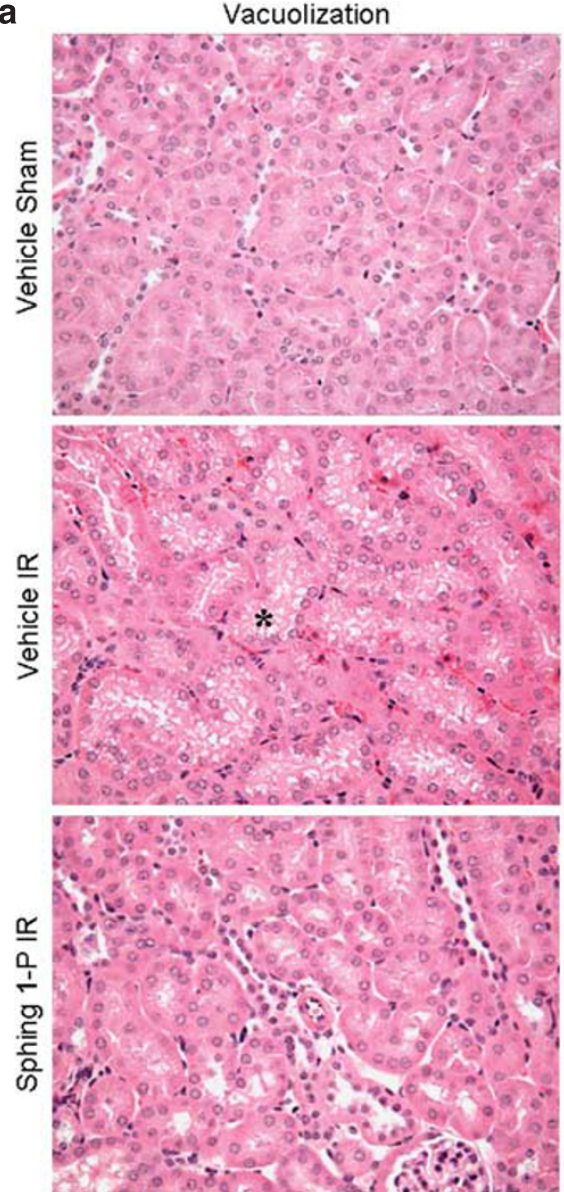

b
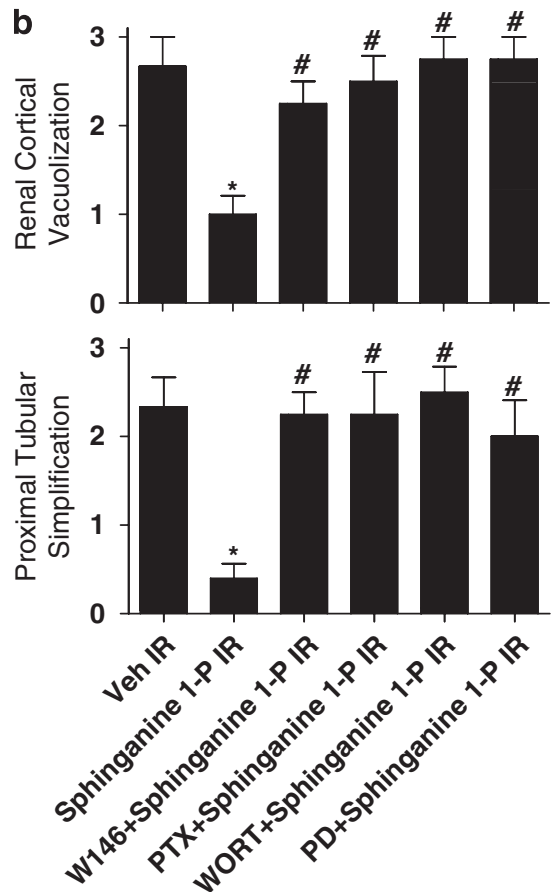

Hypereosinophilia
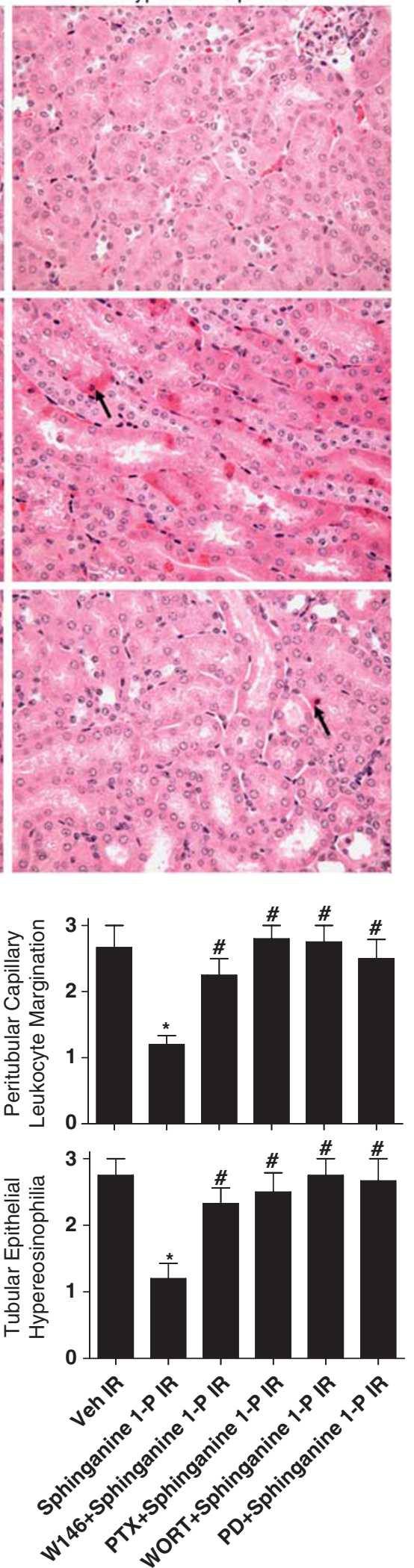
(plasma creatinine, inflammatory markers) changes observed with human AKI associated with liver failure. ${ }^{4}$ Importantly, we noted that AKI after liver IR in our model was associated with a rapid development of renal endothelial cell apoptosis with subsequent vascular impairment, neutrophil infiltration, and renal proximal tubule cell necrosis. ${ }^{4}$ Therefore, we hypothesized and explored ways to improve endothelial integrity that will subsequently reduce renal and hepatic dysfunction after liver IR.

Sphingolipids including sphingosine and sphinganine (dihydrosphingosine) are ubiquitous but essential structural and functional components of the cell. In addition, sphingolipid metabolites including S1P have important biological roles in various physiological as well as pathophysiological events. ${ }^{25}$ Sphinganine-1-phosphate as well as S1P is produced by the ATP-dependent phosphorylation of sphinganine by sphingosine kinases. ${ }^{26,27}$ Sphingosine kinase (SK) is a conserved lipid kinase with two mammalian isoforms (SK1 and SK2). ${ }^{26,27}$ The biological role of S1P has been extensively characterized including cell growth and survival and inflammation. ${ }^{28}$ Furthermore, S1P produces powerful antiapoptotic and pro-survival signaling in endothelial cells. ${ }^{29}$ In contrast to the well-characterized biological and physiological roles of $\mathrm{S} 1 \mathrm{P}^{29,30}$ sphinganine-1-phosphate has not been widely studied and little is known about its function.

We unexpectedly discovered recently that plasma levels of sphinganine-1-phosphate (but not S1P) fell significantly after liver IR in mice. ${ }^{5}$ Moreover, in our present and earlier studies, we showed that exogenous sphinganine-1-phosphate treatment immediately before reperfusion significantly attenuated the elevation of plasma ALT and creatinine levels after hepatic IR. We propose that sphinganine-1-phosphate is biologically potent, is depleted after massive liver IR injury, and may have important cytoprotective functions to defend against endothelial cell dysfunction after liver IR. Although sphinganine-1-phosphate is structurally similar to S1P, it differs from S1P by being cell impermeable ${ }^{31}$ and lacks the trans double bond at the four position. ${ }^{32}$ Liver IR results in depletion of systemic as well as hepatic ATP (a necessary cofactor of the SK enzyme) levels, which may decrease the activities and/or efficiencies of SK. However, it is unclear as to why a selective depletion of plasma sphinganine-1-phosphate and not S1P occurs after liver IR as both sphinganine-1-phosphate and
S1P synthesis depend on the same enzyme, SK. Preferential synthesis of sphinganine-1-phosphate over S1P has been shown with SK1 overexpression. ${ }^{33}$ Berdyshev et al ${ }^{33}$ have shown that SK1 overexpression in several primary cells and cultured cell lines resulted in a predominant upregulation of sphinganine-1-phosphate synthesis relative to S1P. In their study, SK1 overexpression preferentially directed the metabolic flow of newly formed sphingoid bases from de novo ceramide formation toward the synthesis of sphinganine-1phosphate. These studies suggest that SK1 preferentially synthesizes sphinganine-1-phoshate from simple de novo sphingolipids produced whereas formation of S1P is through separate and complex catabolic pathways.

Although $\mathrm{S} 1 \mathrm{P} \rightarrow \mathrm{S} 1 \mathrm{P}$ receptor signaling has been extensively studied, sphinganine-1-phosphate-mediated cell signaling has not been studied in detail. As the structures of sphinganine-1-phosphate and S1P are similar, we postulated that sphinganine-1-phosphate acting on the cell surface S1P receptors may mediate hepatic and renal protection after liver IR. Protective effects of S1P receptor signaling to protect against liver and kidney injury have been shown earlier in vivo. For example, FTY720 (2-amino-2-[2-(4-octylpheny1)ethyl]propane-1,3-diol) protected against liver IR in rats presumably through the activation of S1P receptor modulation. ${ }^{34,35}$ Moreover, several S1P receptor agonists, including S1P, FTY-720, and SEW-2871 (a selective ligand for S1P1 receptor), protected against renal IR injury in vivo through reducing renal proximal tubule influx of T-lymphocytes with subsequent reduction in necrosis and inflammation. . $^{17,36,37}$

We show in this study that sphinganine-1-phosphatemediated liver and kidney protection after liver IR is $\mathrm{S}_{1} \mathrm{P}_{1}$ receptor mediated as a selective $\mathrm{S}_{1} \mathrm{P}_{1}$ receptor antagonist (W146) blocked the protective effects of sphinganine-1phosphate. Selective $\mathrm{S}_{2} \mathrm{P}_{2}$ (JTE-013) and $\mathrm{S} \mathrm{P}_{3}$ (BML-241) antagonists had no effect on sphinganine-1-phosphatemediated liver and kidney protection after liver IR. All of these antagonists for S1P receptors provide extreme selectivity for their respective receptor subtypes. ${ }^{14-16}$ To further evaluate the role of $\mathrm{S}_{1} \mathrm{P}_{1}$ receptors in sphinganine-1phosphate-mediated liver and kidney protection, we used siRNA targeting $\mathrm{S}_{1} \mathrm{P}_{1}$ receptors in mice in vivo to complement the data obtained with pharmacological inhibitor (W146) studies. We were able to selectively downregulate

Figure 6 (a). Representative photomicrographs of six experiments (hematoxylin and eosin staining, magnification $\times 400$ ) demonstrating vacuolization $\left({ }^{*}\right.$ ) and hypereosinophillia (arrows) in kidneys from C57BL/6 mice $24 \mathrm{~h}$ after being subjected sham-operation or to liver ischemia reperfusion after vehicle- or sphinganine-1-phosphate treatment ( $0.1 \mathrm{mg} / \mathrm{kg}$ i.v. immediately before reperfusion and $0.2 \mathrm{mg} / \mathrm{kg}$ s.c. $2 \mathrm{~h}$ after reperfusion). Photographs are representative of six independent experiments. (b). Summary of renal injury scores (scale 0-3) for renal cortical vacuolization, peritubular leukocyte margination, proximal tubule simplification, and renal tubular hypereosinophilia for kidneys from mice subjected to liver IR after vehicle or sphinganine-1-phosphate treatment. Some mice were pretreated with PD98059 (PD, an inhibitor of MEK1 to inhibit ERK phosphorylation, $1 \mathrm{mg} / \mathrm{kg}$, i.p., $N=6)$ or with wortmannin (Wort, an inhibitor of PI3K to inhibit Akt phosphorylation, $1 \mathrm{mg} / \mathrm{kg}$, i.p., $N=6$ ) $20 \mathrm{~min}$ before vehicle or sphinganine-1-phosphate treatment. Some mice were pretreated with pertussis toxin (PTX, $25 \mu \mathrm{g} / \mathrm{kg}$, i.p.) $48 \mathrm{~h}$ before sphinganine-1-phosphate treatment. Mice pretreated with PD98059, wortmannin, or pertussis toxin showed increased indices of renal injury. ${ }^{\star} P<0.05$ vs vehicle-treated IR group. ${ }^{\#} P<0.05$ vs sphinganine-1-phosphate-treated hepatic IR group. 

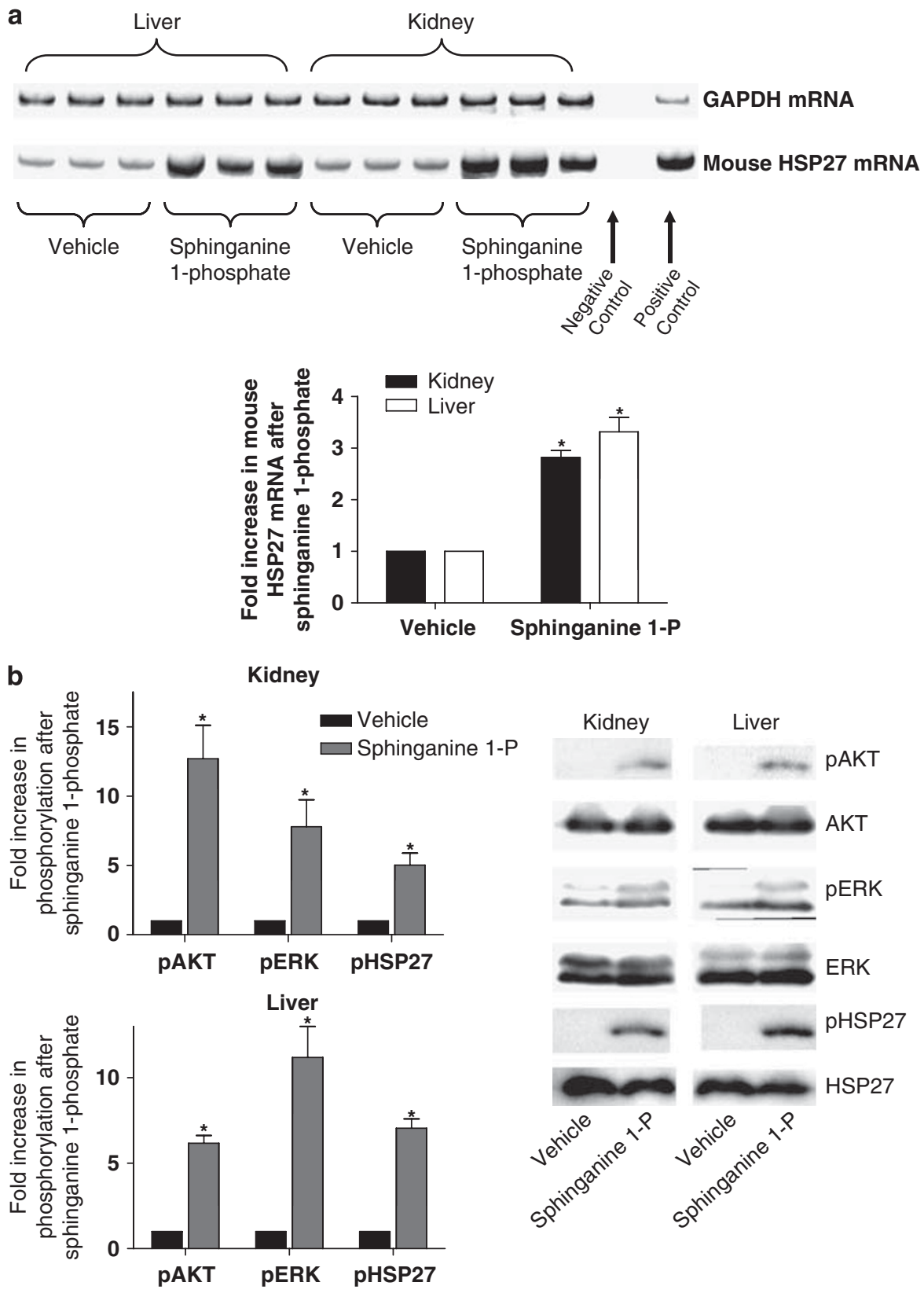

C

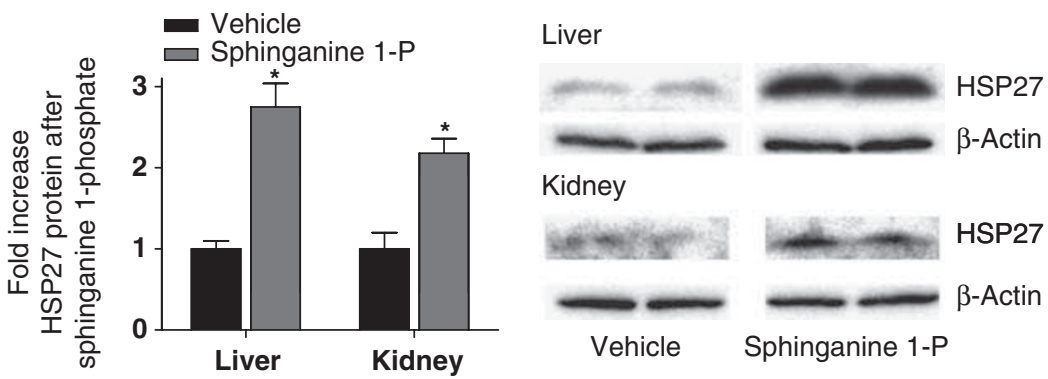

Figure 7 (a) Representative gel images of RT-PCR results GAPDH and mouse HSP27 mRNAs extracted after treatment with vehicle (0.4\% fatty acid free BSA) or $0.1 \mathrm{mg} / \mathrm{kg}$ sphinganine-1-phosphate i.v. before $5 \mathrm{~h}$. Densitometric quantification of relative mRNA band intensities normalized to GAPDH from RT-PCR reactions are shown in the bottom panel $(N=6)$. Data are presented as means \pm s.e.m. ${ }^{\star} P<0.05$ vs vehicle group. (b) Representative immunoblots for phospho (p)- and total ERK, phospho (p)- and total Akt, phospho (p)- and total HSP27 from renal cortices and liver of mice (right panel) after injection with vehicle or $0.1 \mathrm{mg} / \mathrm{kg}$ sphinganine-1-phosphate i.v. before $15 \mathrm{~min}$. (c) Representative immunoblots for total HSP27 and actin (showing equal lane loading) from renal cortices and liver of mice after injection with vehicle or $0.1 \mathrm{mg} / \mathrm{kg}$ sphinganine-1-phosphate i.v. before $24 \mathrm{~h}$. Densitometric quantifications of relative band intensities are also shown (left panel, $N=4$ ). ${ }^{*} P<0.05$ vs vehicle. Error bars, 1 s.e.m. 
a
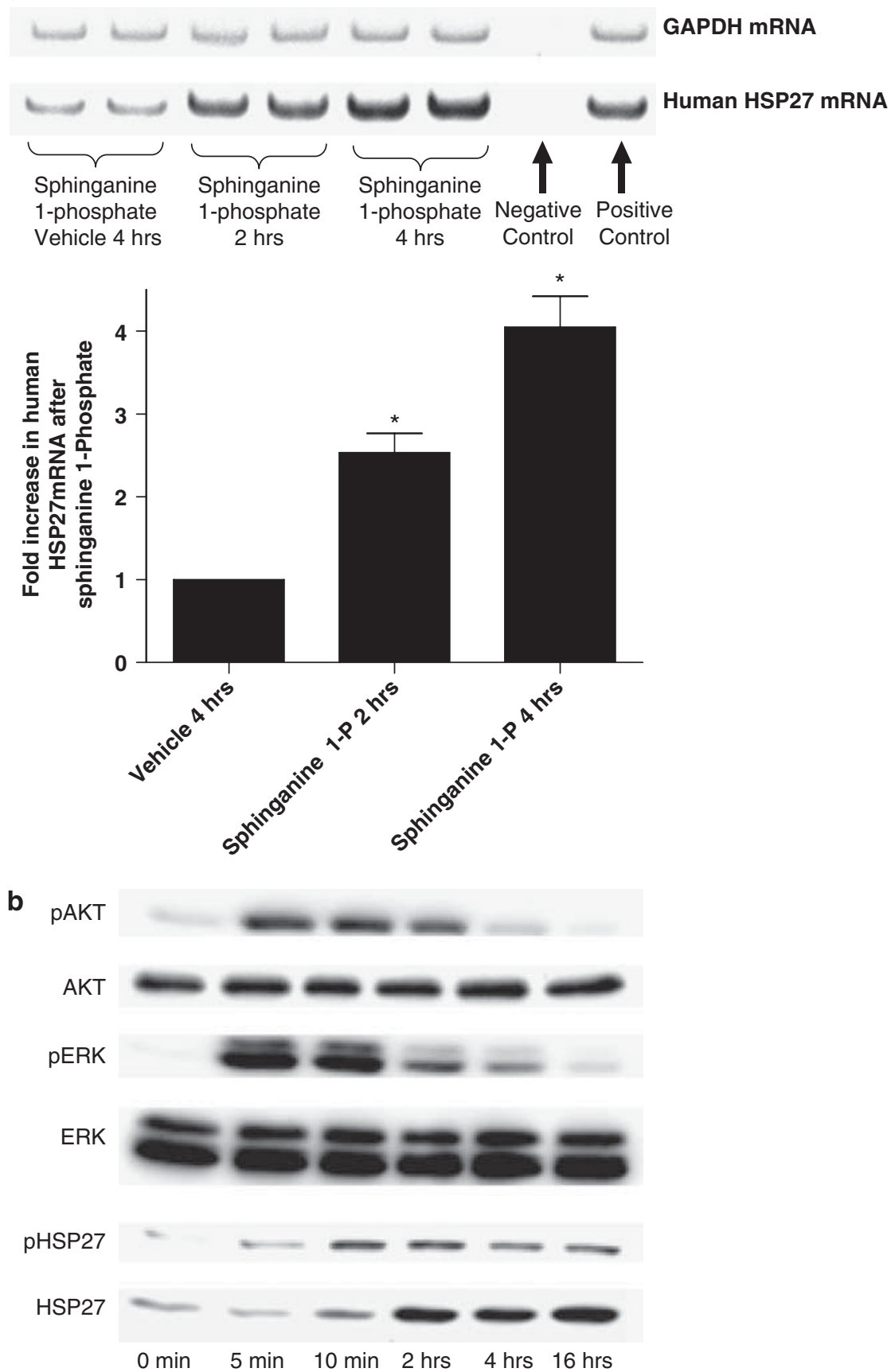

Time after addition of $1 \mu \mathrm{M}$ sphinganine-1-phosphate

Figure 8 (a) Representative gel images of RT-PCR results GAPDH and human HSP27 mRNAs extracted from human renal endothelial cells in culture. Cells were treated with vehicle (0.4\% fatty acid free BSA for $4 \mathrm{~h}$ ) or with sphinganine-1-phosphate (sphinganine-1-P, $1 \mu \mathrm{M}$ for 2 or $4 \mathrm{~h}$ ). Densitometric quantification of relative mRNA band intensities normalized to GAPDH from RT-PCR reactions are shown in the bottom panel. Data are presented as means \pm s.e.m. ${ }^{*} P<0.05$ vs vehicle $4 \mathrm{~h}$ group. (b) Human renal endothelial cells were treated with $1 \mu \mathrm{m}$ sphinganine-1-phosphate for indicated periods and probed for phosphorylation of anti-apoptotic kinases ERK and Akt and phospho and total HSP27 (representative of five experiments).

$\mathrm{S}_{1} \mathrm{P}_{1}$ receptors in adult mice with siSTABLE constructs in vivo (Figure 3), which resulted in complete loss of sphinganine-1-phosphate-mediated hepatic and renal protection after liver IR.
We also show in this study that sphinganine-1-phosphate through $\mathrm{S}_{1} \mathrm{P}_{1}$ receptor activation leads to phosphorylation of ERK MAPK, Akt, and HSP27 as well as induction of HSP27 in mouse kidney and liver (Figure 7) as well as cultured 


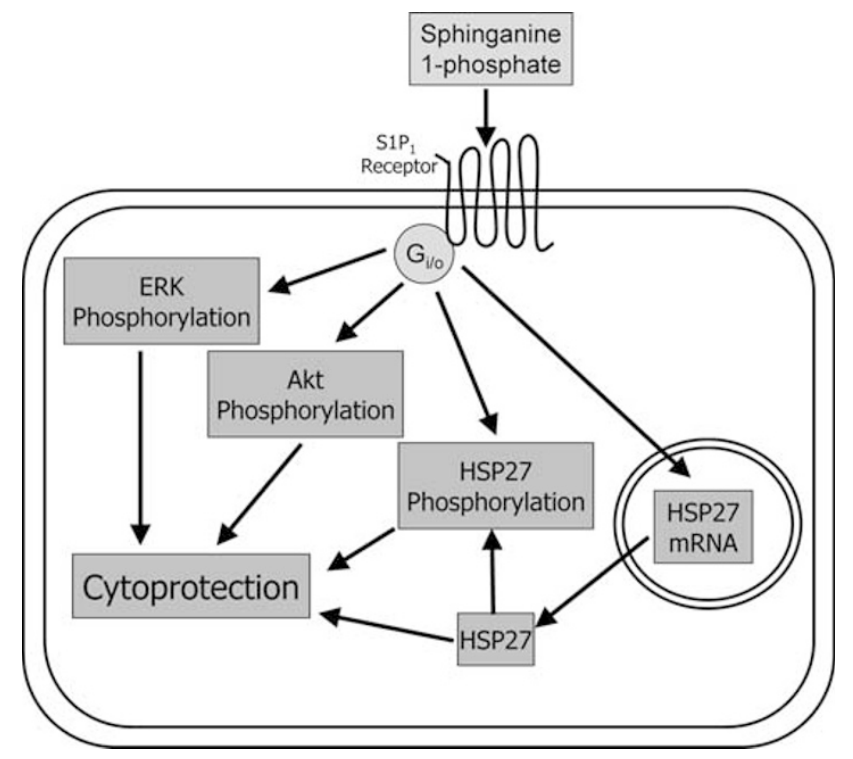

Figure 9 Proposed cellular mechanisms of sphinganine-1-phosphatemediated renal and hepatic protection after liver IR. On the basis of the data generated from our studies, we propose that sphinganine-1phosphate activates the $\mathrm{S}_{1} \mathrm{P}_{1}$ receptor subtype in endothelial cells that couples to pertussis toxin-sensitive G-proteins, resulting in the phosphorylation of ERK MAPK, Akt, as well as HSP27. We also propose induction of HSP27 mRNA as well as protein after sphinganine-1-phosphate treatment.

human renal endothelial cells (Figure 8). Endothelial selectivity is suggested as sphinganine-1-phosphate failed to phosphorylate ERK MAPK, Akt, and HSP27 in human kidney proximal tubule epithelial cell (HK-2) line. The differential molecular mechanisms for these signaling differences between endothelial cells and proximal tubules cells remain to be elucidated. Activation of ERK MAPK is strongly associated with enhanced protection against several forms of injury including necrosis and apoptosis. ${ }^{9,38}$ The serine/ threonine kinase Akt is an important component of cell survival pathways in many cell types. ${ }^{39,40}$ In particular, Akt has diverse functions to counteract apoptosis including inhibition of mitochondrial cytochrome $\mathrm{c}$ and phosphorylation of several pro-apoptotic factors (for example bad, caspase 9 , glycogen synthase kinase 3$).{ }^{10,41}$

HSP27 is a member of family of chaperone proteins that are upregulated in response to a wide range of cellular stresses including hypoxia, ischemia, and exposure to toxic drugs. ${ }^{42-45}$ Increased expression of HSP27 serves to defend a cell against injury or death by acting as chaperones facilitating proper polypeptide folding and aberrant protein removal. ${ }^{46-48}$ Furthermore, HSP27 is a potent anti-apoptotic protein and is a key stabilizer of the actin cytoskeleton; both of these cellular effects lead to increased resistance against cell death. ${ }^{4-51}$ Both phosphorylated and nonphosphorylated forms of HSP27 can reduce cellular injury against diverse forms of stress including renal injury. It remains to be determined whether a direct link exists between HSP27 phosphorylation/induction and sphinganine-1-phosphatemediated liver and kidney protection.

In this study, we were surprised to discover that the hepatic protection with S1P was not only attenuated by an S1P receptor antagonist but was also improved by an $\mathrm{S}_{1} \mathrm{P}_{3}$ selective antagonist. These findings suggest that exogenous S1P activation of $\mathrm{S}_{1} \mathrm{P}_{1}$ receptor provides protective signaling cascade in the liver; however, S1P can also initiate potentially detrimental effects through $\mathrm{S}_{1} \mathrm{P}_{3}$ receptor activation as well. S1P3 receptor activation in pulmonary epithelial cells leads to disruption of tight junctions, possibly by activating Rho resulting in increased lung vascular permeability. ${ }^{52}$ Moreover, the $\mathrm{S}_{1} \mathrm{P}_{3}$ but not the $\mathrm{S}_{1} \mathrm{P}_{1}$ receptor subtype has been implicated in nonselective S1P receptor agonist induced bradycardia. $^{53}$ Indeed, FTY-720 (an immunomodulator analog of S1P) has been shown to not only produce expected lymphomenia but also produced undesirable dose-dependent bradycardia in clinical trials. ${ }^{53}$ Therefore, in contrast to the protective effects of $\mathrm{S}_{1} \mathrm{P}_{1}$ receptor activation, $\mathrm{S}_{1} \mathrm{P}_{3}$ receptor activation may trigger detrimental effects against organ injury. We propose that S1P produces activation of multiple $\mathrm{S} 1 \mathrm{P}$ receptor subtypes (including $\mathrm{S}_{1} \mathrm{P}_{1}$ and $\mathrm{S}_{1} \mathrm{P}_{3}$ ) resulting in conflicting physiological effects. This is in contrast to the lack of $\mathrm{S}_{1} \mathrm{P}_{3}$ receptor-mediated effects observed with sphinganine1-phosphate-mediated hepatic protection (Figure 2).

A limitation of the study is that $\mathrm{S}_{1} \mathrm{P}_{4}$ and $\mathrm{S}_{1} \mathrm{P}_{5}$ receptor selective antagonists are currently not available; therefore, we cannot evaluate the roles for these receptor subtypes in sphinganine-1-phosphate-mediated liver and kidney protection. However, although S1P receptors are ubiquitously expressed in almost every cell type, in the vascular endothelial system $\mathrm{S}_{1} \mathrm{P}_{1}, \mathrm{~S}_{1} \mathrm{P}_{2}$, and $\mathrm{S}_{1} \mathrm{P}_{3}$ receptor subtypes predominate in expression and function. ${ }^{54}$ Another limitation is that, although we implicate endothelial cells as the target of sphinganine-1-phosphate-mediated protection as this drug shows selective phosphorylation of renal endothelial but not renal epithelial cell line, with in vivo studies it is impossible to delineate for certain the target cell type(s) involved in sphinganine-1-phosphate-mediated protection. Future in vitro studies to complement our current in vivo studies are required to determine whether other parenchymal cell types of interest (for example hepatocyte) are also involved.

In conclusion, we determined the mechanisms of sphinganine-1-phosphate (a relatively unknown sphingolipid molecule)-mediated protection against liver IR-induced renal and hepatic injury in mice. Our study shows that activation of the $\mathrm{S}_{1} \mathrm{P}_{1}$ receptor through sphinganine-1-phosphate protects against liver IR-induced AKI and hepatic injury through, Gi/o, ERK, and Akt-mediated mechanisms and the protection is independent of the eNOS pathway. In contrast, activation of $\mathrm{S}_{1} \mathrm{P}_{3}$ receptors attenuated the hepatic protective effects of exogenous S1P after liver IR. We propose that sphinganine-1-phosphate through selective $\mathrm{S}_{1} \mathrm{P}_{1}$ receptor activation without affecting the $\mathrm{S}_{3} \mathrm{P}_{3}$ receptors is superior to S1P in attenuating hepatic IR injury and may be a promising 
pharmacological agent for protecting both liver and kidney function after hepatic IR.

\section{ACKNOWLEDGEMENT}

This work was supported by National Institute of Health Grant RO1 DK-58547 and RO1 GM-067081.

\section{DISCLOSURE/CONFLICT OF INTEREST}

The authors declare no conflict of interest.

1. Serracino-Inglott $F$, Habib NA, Mathie RT. Hepatic ischemia-reperfusion injury. Am J Surg 2001;181:160-166.

2. Fondevila C, Busuttil RW, Kupiec-Weglinski JW. Hepatic ischemia/ reperfusion injury-a fresh look. Exp Mol Pathol 2003;74:86-93.

3. Davis $\mathrm{CL}$, Gonwa TA, Wilkinson AH. Pathophysiology of renal disease associated with liver disorders: implications for liver transplantation.

Part I. Liver Transpl 2002;8:91-109.

4. Lee HT, Park SW, Kim M, et al. Acute kidney injury after hepatic ischemia and reperfusion injury in mice. Lab Invest 2009;89:196-208.

5. Park SW, Kim M, Chen SWC, et al. Sphinganine-1-phosphate attenuates both hepatic and renal injury induced by hepatic ischemia and reperfusion in mice. Shock 2010;33:31-42.

6. Joo JD, Kim M, Horst $P$, et al. Acute and delayed renal protection against renal ischemia and reperfusion injury with $A 1$ adenosine receptors. Am J Physiol Renal Physiol 2007;293:F1847-F1857.

7. Lee $H T$, Emala CW. Protein kinase $C$ and $G(i / o)$ proteins are involved in adenosine- and ischemic preconditioning-mediated renal protection. J Am Soc Nephrol 2001;12:233-240.

8. Lee HT, Emala CW. Characterization of adenosine receptors in human kidney proximal tubule (HK-2) cells. Exp Nephrol 2002;10:383-392.

9. Buckley S, Driscoll B, Barsky L, et al. ERK activation protects against DNA damage and apoptosis in hyperoxic rat AEC2. Am J Physiol 1999:277:L159-L166.

10. Kennedy SG, Kandel ES, Cross TK, et al. Akt/protein kinase B inhibits cell death by preventing the release of cytochrome $c$ from mitochondria. Mol Cell Biol 1999;19:5800-5810.

11. Igarashi J, Michel T. Sphingosine-1-phosphate and modulation of vascular tone. Cardiovasc Res 2009;82:212-220.

12. Van Brocklyn JR, Tu Z, Edsall LC, et al. Sphingosine 1-phosphateinduced cell rounding and neurite retraction are mediated by the $\mathrm{G}$ protein-coupled receptor H218. J Biol Chem 1999;274:4626-4632.

13. Slot C. Plasma creatinine determination. A new and specific Jaffe reaction method. Scand J Clin Lab Invest 1965;17:381-387.

14. Sanna MG, Wang SK, Gonzalez-Cabrera PJ, et al. Enhancement of capillary leakage and restoration of lymphocyte egress by a chiral S1P1 antagonist in vivo. Nat Chem Biol 2006;2:434-441.

15. Koide $Y$, Hasegawa T, Takahashi A, et al. Development of novel EDG3 antagonists using a 3D database search and their structure-activity relationships. J Med Chem 2002;45:4629-4638.

16. Inoki I, Takuwa N, Sugimoto N, et al. Negative regulation of endothelial morphogenesis and angiogenesis by S1P2 receptor. Biochem Biophys Res Commun 2006;346:293-300.

17. Awad AS, Ye H, Huang $L$, et al. Selective sphingosine 1-phosphate 1 receptor activation reduces ischemia-reperfusion injury in mouse kidney. Am J Physiol Renal Physiol 2006;290:F1516-F1524.

18. Joo JD, Kim M, D'Agati VD, et al. Ischemic preconditioning provides both acute and delayed protection against renal ischemia and reperfusion injury in mice. J Am Soc Nephrol 2006;17:3115-3123.

19. Li S, Ohgami Y, Dai $Y$, et al. Antagonism of nitrous oxide-induced anxiolytic-like behavior in the mouse light/dark exploration procedure by pharmacologic disruption of endogenous nitric oxide function. Psychopharmacology (Berl) 2003;166:366-372.

20. Lee HT, Gallos $\mathrm{G}$, Nasr $\mathrm{SH}$, et al. A1 adenosine receptor activation inhibits inflammation, necrosis, and apoptosis after renal ischemiareperfusion injury in mice. J Am Soc Nephrol 2004;15:102-111.

21. Suzuki S, Toledo-Pereyra LH, Rodriguez FJ, et al. Neutrophil infiltration as an important factor in liver ischemia and reperfusion injury. Modulating effects of FK506 and cyclosporine. Transplantation 1993;55:1265-1272.
22. Lee HT, Emala CW. Adenosine attenuates oxidant injury in human proximal tubular cells via $A(1)$ and $A(2 a)$ adenosine receptors. Am J Physiol Renal Physiol 2002;282:F844-F852.

23. Kim M, Chen SW, Park SW, et al. Kidney-specific reconstitution of the A1 adenosine receptor in A1 adenosine receptor knockout mice reduces renal ischemia-reperfusion injury. Kidney Int 2009;75: 809-823.

24. Suzuki S, Toledo-Pereyra LH, Rodriguez FJ, et al. Neutrophil infiltration as an important factor in liver ischemia and reperfusion injury. Modulating effects of FK506 and cyclosporine. Transplantation 1993;55:1265-1272.

25. Jo SK, Bajwa A, Awad AS, et al. Sphingosine-1-phosphate receptors: biology and therapeutic potential in kidney disease. Kidney Int 2008;73:1220-1230.

26. Le Stunff $\mathrm{H}$, Milstien S, Spiegel S. Generation and metabolism of bioactive sphingosine-1-phosphate. J Cell Biochem 2004;92:882-899.

27. Liu H, Chakravarty D, Maceyka M, et al. Sphingosine kinases: a novel family of lipid kinases. Prog Nucl Acid Res Mol Biol 2002;71:493-511.

28. Hait NC, Oskeritzian CA, Paugh SW, et al. Sphingosine kinases, sphingosine 1-phosphate, apoptosis and diseases. Biochim Biophys Acta 2006;1758:2016-2026.

29. Venkataraman K, Thangada S, Michaud J, et al. Extracellular export of sphingosine kinase-1a contributes to the vascular S1P gradient. Biochem J 2006;397:461-471.

30. Chalfant CE, Spiegel S. Sphingosine 1-phosphate and ceramide 1-phosphate: expanding roles in cell signaling. J Cell Sci 2005;118:4605-4612.

31. Gonzalez-Diez M, Rodriguez C, Badimon L, et al. Prostacyclin induction by high-density lipoprotein $(\mathrm{HDL})$ in vascular smooth muscle cells depends on sphingosine 1-phosphate receptors: effect of simvastatin. Thromb Haemost 2008;100:119-126.

32. Fossetta J, Deno G, Gonsiorek W, et al. Pharmacological characterization of human S1P4 using a novel radioligand, [4,5-3H]dihydrosphingosine-1-phosphate. Br J Pharmacol 2004;142:851-860.

33. Berdyshev EV, Gorshkova IA, Usatyuk P, et al. De novo biosynthesis of dihydrosphingosine-1-phosphate by sphingosine kinase 1 in mammalian cells. Cell Signal 2006;18:1779-1792.

34. Anselmo DM, Amersi FF, Shen XD, et al. FTY720 pretreatment reduces warm hepatic ischemia reperfusion injury through inhibition of Tlymphocyte infiltration. Am J Transplant 2002;2:843-849.

35. Man K, Ng KT, Lee TK, et al. FTY720 attenuates hepatic ischemiareperfusion injury in normal and cirrhotic livers. Am J Transplant 2005;5:40-49.

36. Lai LW, Yong KC, Igarashi S, et al. A sphingosine-1-phosphate type 1 receptor agonist inhibits the early T-cell transient following renal ischemia-reperfusion injury. Kidney Int 2007;71:1223-1231.

37. Lien YH, Yong KC, Cho C, et al. S1P(1)-selective agonist, SEW2871, ameliorates ischemic acute renal failure. Kidney Int 2006;69:1601-1608.

38. Fryer RM, Hsu AK, Gross GJ. ERK and p38 MAP kinase activation are components of opioid-induced delayed cardioprotection. Basic Res Cardiol 2001;96:136-142.

39. Hausenloy D, Mocanu M, Yellon D. Cross-talk between the survival kinases during reperfusion in ischaemic preconditioning. Cardiovasc J S Afr 2004;15:S11.

40. Hausenloy DJ, Tsang A, Mocanu MM, et al. Ischemic preconditioning protects by activating prosurvival kinases at reperfusion. Am J Physiol Heart Circ Physiol 2005;288:H971-H976.

41. Cross TG, Scheel-Toellner D, Henriquez NV, et al. Serine/threonine protein kinases and apoptosis. Exp Cell Res 2000;256:34-41.

42. Garrido C, Bruey JM, Fromentin A, et al. HSP27 inhibits cytochrome c-dependent activation of procaspase-9. FASEB J 1999;13:2061-2070.

43. Bruey JM, Ducasse $C$, Bonniaud $P$, et al. Hsp27 negatively regulates cell death by interacting with cytochrome $c$. Nat Cell Biol 2000;2: 645-652.

44. Arrigo AP, Firdaus WJ, Mellier G, et al. Cytotoxic effects induced by oxidative stress in cultured mammalian cells and protection provided by Hsp27 expression. Methods 2005;35:126-138.

45. Arrigo AP. Hsp27: novel regulator of intracellular redox state. IUBMB Life 2001;52:303-307.

46. Wyttenbach A, Sauvageot O, Carmichael J, et al. Heat shock protein 27 prevents cellular polyglutamine toxicity and suppresses the increase of reactive oxygen species caused by huntingtin. Hum Mol Genet 2002;11:1137-1151. 


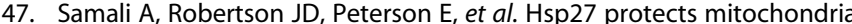
of thermotolerant cells against apoptotic stimuli. Cell Stress Chaperones 2001;6:49-58.

48. Paul C, Manero F, Gonin S, et al. Hsp27 as a negative regulator of cytochrome $C$ release. Mol Cell Biol 2002;22:816-834.

49. Weber NC, Toma O, Wolter Jl, et al. Mechanisms of xenon- and isoflurane-induced preconditioning-a potential link to the cytoskeleton via the MAPKAPK-2/HSP27 pathway. Br J Pharmacol 2005; 146:445-455.

50. Landry J, Huot J. Regulation of actin dynamics by stress-activated protein kinase 2 (SAPK2)-dependent phosphorylation of heat-shock protein of 27 kDa (Hsp27). Biochem Soc Symp 1999;64:79-89.
51. Huot J, Houle F, Spitz DR, et al. HSP27 phosphorylation-mediated resistance against actin fragmentation and cell death induced by oxidative stress. Cancer Res 1996;56:273-279.

52. Shikata Y, Birukov KG, Garcia JG. S1P induces FA remodeling in human pulmonary endothelial cells: role of Rac, GIT1, FAK, and paxillin. J Appl Physiol 2003;94:1193-1203.

53. Sanna MG, Liao J, Jo $E$, et al. Sphingosine 1-phosphate (S1P) receptor subtypes S1P1 and S1P3, respectively, regulate lymphocyte recirculation and heart rate. J Biol Chem 2004;279:13839-13848.

54. Kono $\mathrm{M}, \mathrm{Mi} \mathrm{Y}$, Liu $\mathrm{Y}$, et al. The sphingosine-1-phosphate receptors S1P1, S1P2, and S1P3 function coordinately during embryonic angiogenesis. J Biol Chem 2004;279:29367-29373. 